\title{
Aerosol direct radiative forcing based on GEOS-Chem-APM and uncertainties
}

\author{
X. Ma, F. Yu, and G. Luo \\ Atmospheric Sciences Research Center, State University of New York, 251 Fuller Road, Albany, New York 12203, USA \\ Correspondence to: X. Ma (xma@albany.edu)
}

Received: 22 November 2011 - Published in Atmos. Chem. Phys. Discuss.: 3 January 2012

Revised: 27 April 2012 - Accepted: 1 June 2012 - Published: 26 June 2012

\begin{abstract}
Aerosol direct radiative forcing (DRF) plays an important role in global climate change but has a large uncertainty. Here we investigate aerosol DRF with GEOSChem-APM, a recently developed global aerosol microphysical model that is designed to capture key particle properties (size, composition, coating of primary particles by volatile species, etc.). The model, with comprehensive chemistry, microphysics and up-to-date emission inventories, is driven by assimilated meteorology, which is presumably more realistic compared to the model-predicted meteorology. For this study, the model is extended by incorporating a radiation transfer model. Optical properties are calculated using Mie theory, where the core-shell configuration could be treated with the refractive indices from the recently updated values available in the literature. The surface albedo is taken from MODIS satellite retrievals for the simulation year, in which the data set for the 8-day mean at $0.05^{\circ}(5600 \mathrm{~m})$ resolution for 7 wavebands is provided. We derive the total and anthropogenic aerosol DRF, mainly focus on the results of anthropogenic aerosols, and then compare with those values reported in previous studies. In addition, we examine the anthropogenic aerosol DRF's dependence on several key factors, including the particle size of black carbon (BC) and primary organic carbon (POC), the density of $\mathrm{BC}$ and the mixing state. Our studies show that the anthropogenic aerosol DRF at top of atmosphere (TOA) for all sky is $-0.41 \mathrm{~W} \mathrm{~m}^{-2}$. However, the sensitivity experiments suggest that the magnitude could vary from $-0.08 \mathrm{~W} \mathrm{~m}^{-2}$ to $-0.61 \mathrm{~W} \mathrm{~m}^{-2}$, depending on assumptions regarding the mixing state, size and density of particles.
\end{abstract}

\section{Introduction}

Radiative forcing of atmospheric aerosols plays an important role in global climate change, but it still remains the largest uncertainty among the various climate forcing factors (IPCC, 2007). The uncertainties can be attributed to a number of issues, such as the emission of precursor gases and primary particles, parameterizations of physical and chemical processes, meteorological conditions, optical properties of aerosol particles, etc. There is a large amount of previous studies aiming to quantify the uncertainties, e.g. the AeroCom aerosol microphysics inter-comparison project, in which the unified emission inventory was applied to all models. According to AeroCom inter-comparison, large differences exist in aerosol burden and DRF, despite the emissions being exactly the same. Also, model diversity was not greatly reduced by unifying emissions, indicating that the greatest model differences are due to features such as meteorology and aerosol treatments rather than from emissions (Kinne et al., 2006; Textor et al., 2007).

Aerosol properties, including aerosol size distribution, morphology, density and refractive index, are also crucial to DRF. In many previous studies, aerosol size distribution is often prescribed as a log-normal distribution (Lohmann et al., 1999; Takemura et al., 2000) to avoid huge computational burdens associated with size-resolved microphysics simulations. The corresponding optical properties are calculated based on the prescribed size distribution. With the advancements in computer technology, the aerosol size distribution has been explicitly predicted online by a number of models in recent years (Liu et al., 2005; Ma and von Salzen, 2006; Yu and Luo, 2009). However, the predicted aerosol size distributions in various models remain quite different. 
The ongoing AeroCom project "aerosol microphysics intercomparison" will compare the modeled aerosol size distributions in terms of various observations and quantify the uncertainties of model results. The study of Koch et al. (2009) demonstrated that aerosol absorption optical depth (AAOD) of $B C$ is quite sensitive to the particle size. Their study showed that AAOD at $550 \mathrm{~nm}$ is much higher (0.007) for a particle effective radius of $0.06 \mu \mathrm{m}$, compared with the value of 0.0047 for a radius of $0.1 \mu \mathrm{m}$.

Density of BC in various model studies has been found to range from 1.0 to $2.0 \mathrm{~g} \mathrm{~cm}^{-3}$ (Koch et al., 2009), which is one of the reasons behind the large diversity of aerosol radiative forcing. Jacobson (2000) estimated the impact of BC density on radiative forcing, and concluded that $\mathrm{BC}$ forcing increases from 0.41 to $0.54 \mathrm{~W} \mathrm{~m}^{-2}$ when the density of $\mathrm{BC}$ decreases from 1.75 to $1.25 \mathrm{~g} \mathrm{~cm}^{-3}$. Bond and Bergstrom (2006) reviewed a large amount of measurements and recommended that the density of $\mathrm{BC}$ should be $1.7-1.9 \mathrm{~g} \mathrm{~cm}^{-3}$ and that the use of $1.0 \mathrm{~g} \mathrm{~cm}^{-3}$ should be abandoned. This implies that the $\mathrm{BC}$ absorption and DRF in many previous studies, assuming lower BC density, have been overestimated.

The refractive index varies with the aerosol chemicals. For weakly-absorbing aerosol species, e.g. sulfate and sea salt, the refractive indices used in the model are commonly accepted. However, for strongly-absorbing particles, e.g. BC and dust, there is not yet a consensus for the values of refractive indices. Bond and Bergstrom (2006) pointed out that the value for BC commonly used by climate models $(m=1.74$ $0.44 i$ at $550 \mathrm{~nm}$ ) represents none of the possible refractive indices. Instead, they recommended that a refractive index of $1.95-0.79 i$ at $550 \mathrm{~nm}$, based on the most measurements reported in the literature, be used instead. Stier et al. (2007) investigated how the values of refractive index applied in the global model impact the radiative forcing, and found that atmospheric absorption for anthropogenic aerosols increases from 0.74 to $1.21 \mathrm{~W} \mathrm{~m}^{-2}$, and all-sky TOA forcing decreases from -2.51 to $-2.24 \mathrm{~W} \mathrm{~m}^{-2}$ if $\mathrm{BC}$ refractive index changes from $1.75-0.44 i$ to $1.95-0.79 i$.

Surface conditions, in particular surface albedo, impact DRF significantly. Aerosol forcing, for both TOA and surface forcing is generally more negative for lower surface albedo and less negative when surface albedo increases. For scattering aerosol particles, forcing is always negative except when surface albedo is close to unity ( $\mathrm{Li}$ et al., 2008). However, the behavior of absorbing particles is quite different. For example, the study of Liao and Seinfeld (1998) shows that dust forcing for clear-sky conditions increases from negative (cooling) to positive (heating) as surface albedo increases, whereas TOA forcing for all-sky is positive for all surface albedo. Stier et al. (2007) tested the sensitivity of radiative forcing on surface albedo, and their results showed that the total aerosol forcing at TOA for clear-sky (all-sky) is -4.29 $(-2.62)$ and $-3.55(-2.09) \mathrm{W} \mathrm{m}^{-2}$ for the AeroCom minimum surface albedo (global mean of 0.18 ) and the maximum surface albedo (global mean of 0.36 ).
Aerosol mixing state is also critical for aerosol optical depth and DRF. Murphy et al. (1998) found that almost all aerosols $>0.13 \mu \mathrm{m}$ in the remote South Pacific Ocean boundary layer contained sea salt, indicating that externally-mixed particles were rare. Mixing rules and their impact on DRF have been explored by previous studies (Chylek et al., 1995; Lesins et al., 2002), which found that absorption of internally mixed $\mathrm{BC}$ is amplified compared to the externally mixed case. Experiments in aerosol chamber also measured this amplification (Schnaiter et al., 2005). In fact, BC particles are irregularly shaped and mostly solid, so BC is not wellmixed (i.e. internal mixing) with other components. Instead, the mixing is a core-shell configuration with $\mathrm{BC}$ particles serving as the core and other soluble particles functioning as the shell. Jacobson's $(2000,2001)$ simulations found that $\mathrm{BC}$ forcing with the core-shell treatment is $50 \%$ higher than forcing obtained with the externally-mixed treatment, and it was suggested that the real forcing by BC probably fell between that from an external mixture and that from a coated core.

In addition to the factors mentioned above, meteorological condition has also been recognized to be important on modeled aerosol burden and radiative forcing. Liu et al. (2007) assessed the uncertainties of DRF in global modeling using three meteorological datasets and found that aerosol burden and DRF can be quite different. It is clear that all these factors complicate the understating of aerosol DRF. Although previous studies have been conducted, large uncertainties still remain. Further studies are needed.

GEOS-Chem is a global chemical transport model and is able to simulate comprehensive chemical reactions and produce the prognostic chemical species (e.g. Bey et al., 2001), rather than the prescribed chemical species as done by many previous global climate models. Therefore, the chemical fields associated with aerosol production are likely to be more accurate, reducing the uncertainties of aerosol prediction. Also, the model is driven by assimilated meteorology, which is presumably more reasonable than the model-produced meteorology. Recently, Yu and Luo (2009) incorporated an advanced particle microphysics (APM) model into GEOS-Chem. The resulting GEOS-Chem-APM is a prognostic multi-type, multi-component, size-resolved aerosol microphysics model, including state-of-the-art nucleation schemes and condensation of low volatile secondary organic compounds from successive oxidation aging. Many previous modeling studies often assume particles are either externally mixed (particles of different components totally separated, i.e. zero mixing) or internally mixed (all aerosol components are completely mixed, i.e. $100 \%$ mixing). In the real atmosphere, particles exist between these two extreme cases and the degree of the mixing states of particles varies with time and location. The GEOS-Chem-APM is designed to explicitly predict the spatiotemporal variations in the degree of particle mixing, which is important for their climatic impact through both direct and indirect effect. 
Given the advantages of GEOS-Chem-APM, the main objective of this study is to investigate DRF of aerosols, particularly anthropogenic aerosols, based on the GEOS-ChemAPM model. Possible uncertainties of simulations will be discussed as well. The paper is organized as follows. In Sect. 2, the model description and experiment setup are outlined. In Sect. 3, the results of model simulations and comparisons with observations are described. In Sect. 4, we mainly focus on the results of anthropogenic aerosol DRF and discuss the uncertainties. Summary will be given in Sect. 5.

\section{Model description and extensions}

We employ the GEOS-Chem-APM model, in which a sizeresolved aerosol microphysics model has been coupled with a global chemistry transport model (GEOS-Chem). In order to study aerosol optical depth (AOD) and DRF, the model has been extended by including a look-up table derived from Mie code to calculate aerosol optical properties (Yu et al., 2012), and a radiation transfer model to estimate radiation fluxes.

\subsection{GEOS-Chem-APM model}

The GEOS-Chem model is a global 3-D model of atmospheric composition driven by assimilated meteorological observations from the Goddard Earth Observing System (GEOS) of the NASA Global Modeling Assimilation Office (GMAO). The model has been developed and used by many research groups and contains a number of state-of-theart modules treating various chemical and aerosol processes (e.g. Bey et al., 2001; Martin et al., 2003; Park et al., 2004; Evans and Jacob, 2005; Liao et al., 2007; Fountoukis and Nenes, 2007) with up-to-date key emission inventories (e.g. Guenther et al., 2006; Bond et al., 2007).

The APM model, incorporated into GEOS-Chem by $\mathrm{Yu}$ and Luo (2009), is an advanced multi-type, multicomponent, size-resolved microphysics model. The basic microphysical processes in the model include nucleation, condensation/evaporation, coagulation, thermodynamic equilibrium with local humidity, and dry and wet deposition. The APM model is very flexible in specifying the number of bins, number of compositions, and number of types of aerosols to be simulated. In the model, a number of schemes/algorithms that improve the computing efficiency have been designed (Yu and Luo, 2009). Pre-calculated look-up tables are extensively used for nucleation rate and coagulation kernel calculations, which substantially reduce the computing time. The bin resolution can be variable, which means that a high size resolution can be used for a certain size range while low resolution is used for other size ranges. The model also allows different time steps and automatically decides the optimum time steps for computing efficiency without sacrificing accuracy. Prognostic aerosol compositions include sec- ondary particles (SP, containing sulfate, ammonia, nitrate and SOAs), BC, primary organic carbon (POC), sea salt and mineral dust. The current GEOS-Chem-APM employs 40 bins for SP to cover the dry diameter size range of $0.0012 \mu \mathrm{m}$ to $12 \mu \mathrm{m}, 20$ bins for sea salt to cover the dry diameter size range of $0.012 \mu \mathrm{m}$ to $12 \mu \mathrm{m}$, and 15 bins for dust particles to cover size range of $0.03 \mu \mathrm{m}$ to $50 \mu \mathrm{m}$. In addition, two log-normal modes with one for fossil fuel (median diameter of $60 \mathrm{~nm}$ ) and another for biomass burning (median diameter of $150 \mathrm{~nm}$ ) are employed to represent hydrophobic BC and another two log-normal modes for hydrophilic BC. Similarly, 4 log-normal modes are used to represent hydrophobic and hydrophilic POC. The formation of new particles is calculated with the ion-mediated nucleation mechanism (Yu, 2010). The contributions of nitrate, ammonium, and SOAs to secondary particle growth are considered. The coating of secondary species on primary particles (sea salt, BC, POC, and dust) is explicitly simulated. The model has been validated with a large number of relevant aerosol measurements (Yu and Luo, 2009; Yu et al., 2010; Yu, 2011).

\subsection{Mie calculation of aerosol optical properties}

The key particle optical properties used for aerosol DRF calculation include extinction efficiency $\left(Q_{\text {ext }}\right)$, single scattering albedo $(w)$, and asymmetry parameter $(g)$. A computationally efficient scheme, in terms of lookup tables, has been designed and developed to calculate online the aerosol optical properties that take advantage of important particle information (sizes, compositions, coating of primary particles by volatile species, hygroscopic growth, etc.) predicted by APM (Yu et al., 2012). The lookup tables are derived from the core-shell Mie scattering model of Ackerman and Toon (1981). The values of $Q_{\text {ext }}, w$ and $g$ depend on wavelength $(\lambda)$, core diameter $\left(d_{\text {core }}\right)$, shell diameter $\left(d_{\text {shell }}\right)$, and real $\left(k_{\mathrm{r}}\right)$ and imaginary $\left(k_{\mathrm{i}}\right)$ components of refractive index $\left(k=k_{\mathrm{r}}-k_{\mathrm{i}} i\right)$. The refractive indices for sulfate, ammonia, nitrate, SOA, POC, and water are according to the corresponding values given in Aouizerats et al. (2010). The refractive indices for sea salt, BC, and dust are based on values recommended by Krekov (1993), Bond and Bergstrom (2006), and Balkanski et al. (2007). The values of refractive indices at $550 \mathrm{~nm}$ are listed in Table 1. For given values of $\lambda, d_{\text {core }}, d_{\text {shell }}, k_{\mathrm{r}}$ and $k_{\mathrm{i}}$, aerosol optical properties ( $Q_{\text {ext }}$, $w$ and $g$ ) can be obtained using the look-up table with an efficient multiple-variable interpolation scheme. The global aerosol optical properties predicted by GEOS-Chem-APM have been compared with AERONET, MODIS, and MISR measurements and reasonable agreement has been achieved. More detailed information about the calculation of aerosol optical properties in GEOS-Chem-APM can be found in Yu et al. (2012). 
Table 1. Refractive indices used for the aerosol components at $550 \mathrm{~nm}$.

\begin{tabular}{ll}
\hline Sulfate & $1.52-5.0 \mathrm{e}-4 i$ \\
\hline Nitrate & $1.53-5.0 \mathrm{e}-3 i$ \\
Ammonia & $1.52-5.0 \mathrm{e}-4 i$ \\
Water & $1.33-1.8 \mathrm{e}-8 i$ \\
SOA & $1.45-0.001 i$ \\
POC & $1.45-0.001 i$ \\
BC & $1.85-0.71 i$ \\
Sea salt & $1.45-1.5 \mathrm{e}-4 i$ \\
Dust & $1.519-1.6 \mathrm{e}-3 i$ \\
\hline
\end{tabular}

\subsection{Radiation transfer model}

The 1-D radiation transfer model of the Canadian Center for Climate Modeling and Analysis (CCCma) has been adapted and incorporated into the GEOS-Chem-APM to calculate shortwave fluxes over 4 solar bands $(0.20-0.69,0.69-1.19$, $1.19-2.38,2.38-4.00 \mu \mathrm{m})$ and longwave fluxes over 9 infrared spectral intervals $(4.0-4.5,4.5-5.5,5.5-6.5,6.5-9.0$,

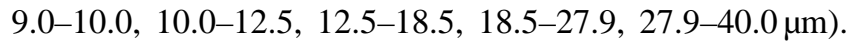
The model includes molecular Rayleigh scattering, gas absorption, cloud effects, and aerosol scattering and absorption. This radiation model is a correlated $\mathrm{k}$-distribution scheme for gaseous transmission (Li, 2002; Li and Barker, 2002; Li and Barker, 2005). For shortwave radiation, water vapor, $\mathrm{CO}_{2}$, $\mathrm{O}_{3}, \mathrm{CH}_{4}$ and $\mathrm{O}_{2}$ are considered for gaseous transmission. For longwave radiation, water vapor, $\mathrm{CO}_{2}, \mathrm{O}_{3}, \mathrm{CH}_{4}, \mathrm{~N}_{2} \mathrm{O}$, $\mathrm{CFC}_{11}$ and $\mathrm{CFC}_{12}$ are considered for gaseous transmission.

This radiation transfer model had been integrated into CCCma global climate models (CCCma/CCC, McFarlane et al., 1992; CCCma/AGCM, Scinocca et al., 2008) since IPCC TAR (IPCC, 2001) for climate studies in the last few decades, weather forecast models (GEM, Côté et al., 1998) and air quality prediction models (GEM-MACH, Talbot et al., 2008) within Environment Canada. CCCma GCMs (general circulation models) is one of 7 GCMs participating in IPCC climate change assessment since 1990 (IPCC, 1990, 2001, 2007). Some previous work on radiative forcing of aerosols based on this radiation transfer model can be found in the studies of Li et al. (2008) and Ma et al. (2008).

In the present study, the atmospheric vertical profiles of pressure, temperature, ozone and water vapor mixing ratios are provided by GEOS-Chem meteorological fields. The sun zenith angle, cloud cover and cloud water content (both liquid and ice) are also taken from GEOS-Chem. The cloud optical properties (specific extinction, single scattering albedo and asymmetry parameter) are parameterized for each band as a function of cloud droplet size and concentration. The effective radius for liquid and ice cloud particles are taken from CERES satellite data (Ma et al., 2010). With the cloud water contents and effective particle sizes, the cloud optical properties for each band are computed at solar (Dobbie et al.,
1999) and infrared (Lindner and Li, 2000) wavebands and for ice cloud particles at solar (Fu, 1996) and infrared (Fu et al., 1998) wavebands.

The assimilated surface albedo in GEOS-Chem is for visible band and UV band only. Although the dependence of radiative forcing on surface albedo has been investigated in earlier studies using a 1-D column radiation transfer model (Liao and Seinfeld, 1998; Li et al., 2008), large uncertainties exist for the radiative forcing caused by surface albedo. This is because surface albedo used in the current global models remains quite uncertain; e.g. Stier et al. (2007) derived the upper and lower estimates of the global surface albedo distribution from AeroCom models and found the radiative differences could be quite different. Currently, surface albedo could be explicitly predicted by coupling a land surface model in GCMs, but the modeled surface albedo largely depends on whether the land surface model could predict surface albedo accurately enough. In addition, prescribed surface albedo used in global models is often for solar broadband or visible-band albedo, instead of spectral-dependent surface albedo. In this study, surface albedo over land is replaced by MODIS satellite retrieval product MOD43B3 from LP DAAC (Land Processes Distributed Active Archive Center, NASA, 2001). The data provides the 8-day mean surface albedo, at $5.6 \mathrm{~km}$ resolution, for MODIS wavebands 1-7 (620-670 nm, 841-876 nm, 459-479 nm, 545-565 nm, $1230-1250 \mathrm{~nm}, 1628-1652 \mathrm{~nm}, 2105-2155 \mathrm{~nm})$. The surface albedo in the MODIS bands 1-7 is interpolated to the four bands of the CCCma radiation transfer model.

\section{Modeled aerosol properties and comparisons}

The GEOS-Chem v8-03-02, with a horizontal resolution of $4^{\circ} \times 5^{\circ}$ and 47 vertical layers up to $0.01 \mathrm{hPa}$ (GEOS- 5 meteorological fields), is used for the present simulation. The simulations start from October 2005 with the first three months as spin up. A one year simulation in 2006 is used for analysis. The assimilated meteorological dataset and the aerosol primary and precursor emissions for this year are used as input. The calculated aerosol burden, optical depth and DRF are presented in this section.

\subsection{Aerosol emission and burden}

Sulfur emission is based on the Emissions Database for Global Atmospheric Research (EDGAR) inventory (Olivier et al., 2001), while the emissions over the United States, Canada, Mexico, Europe and East Asia are replaced by the Environmental Protection Agency (EPA/NEI05) inventory, the Criteria Air Contaminants (CAC) emissions density maps, the Big Bend Regional Aerosol and Visibility Observational (BRAVO) Study emissions inventory (Mark et al., 2003), the European Monitoring and Evaluation Program (EMEP) inventory and the Transport and Chemical Evolution 
over the Pacific (TRACE-P) inventory (Streets et al., 2003), respectively.

Carbonaceous aerosol emissions mainly result from fossil fuel and bio-fuel combustion and biomass burning. In this study, anthropogenic carbonaceous emissions used Bond et al. (2004)'s fossil fuel and bio-fuel inventories, while biomass burning emission is based on Global Fire Emissions Database Version2 (GFED2) monthly open fire inventory (van der Werf et al., 2006). Carbonaceous aerosols in GEOS-Chem are divided into hydrophilic and hydrophobic species. Conversion of hydrophobic to hydrophilic carbonaceous aerosols takes place with an e-folding time of 1.2 days based on Cooke et al. (1999).

Size-resolved sea salt production is parameterized by Gong et al. (1997). Earlier studies indicate that the schemes of sea salt production, which depend on wind speed solely, often fail to capture the sea salt production over the tropics (Gong et al., 1997; Ma et al., 2008). A recent study by Jaegle et al. (2011) combined in situ measurements of aerosol optical depth from MODIS and AERONET and global model simulations to provide new constraints on sea salt production over the ocean. They derived an empirical sea salt source function depending on both wind speed and SST. We applied this modified scheme in GEOS-Chem-APM for the study.

The size-dependent emission of dust particles is calculated with the dust emission module described in Fairlie et al. (2007). Global ammonia and $\mathrm{NO}_{\mathrm{x}}$ sources are as described by Park et al. (2006). The emissions of volatile organic compounds are described in Liao et al. (2007).

The anthropogenic aerosol emissions in GEOS-ChemAPM are listed in Table 2. The total sulfur emission $\left(\mathrm{S}^{+}\right)$ is $52.5 \mathrm{Tg} \mathrm{yr}^{-1}$, with $51.1 \mathrm{Tg} \mathrm{yr}^{-1}$ from fossil fuel, and 1.2 and $0.2 \mathrm{Tg} \mathrm{yr}^{-1}$ from wildfires and biofuel, which is slightly lower than the emissions from AeroCom $\left(55.7 \mathrm{Tg} \mathrm{yr}^{-1}\right)$. The emission of BC and POC (6.3 and $31.5 \mathrm{Tg} \mathrm{yr}^{-1}$ ) are quite similar to those in AeroCom ( 6.4 and $\left.31.7 \mathrm{Tg} \mathrm{yr}^{-1}\right)$. The natural sulfur emissions summarized in Table 3 shows that the sulfur emissions in GEOS-Chem-APM are also quite similar to that in AeroCom.

The modeled annual mean aerosol burden is presented in Fig. 1. It is shown that the GEOS-Chem-APM model could reasonably reproduce the major features and spatial patterns for the different aerosol species, e.g. high SP burden over the industrial areas in the Northern Hemisphere, high sea salt burden over the Southern Ocean and North Pacific and Atlantic due to strong winds, high POC and BC over South Africa and South America due to biomass burning and over Europe, and especially in East Asia mainly due to industrial emissions, and high dust burden in North Africa, East Asia and Australia. In addition, the high SP burden was found over South America and Africa. As mentioned in Sect. 2.1, SP in this study includes the contribution of $\mathrm{SO}_{4}, \mathrm{NH}_{4}, \mathrm{NO}_{3}$, $\mathrm{SOA}$ and MSA, so the SP contribution in these regions is mainly due to SOA. Secondary Species (SS) coated on primary particles are generally much lower than those remaining in SP,
Table 2. Anthropogenic aerosol emissions based on GEOS-ChemAPM and comparison with AeroCom. Unit: $\mathrm{Tg} \mathrm{S} \mathrm{yr}^{-1}$ for sulfur $\left(\mathrm{S}^{+}\right), \mathrm{Tg} \mathrm{C} \mathrm{yr}^{-1}$ for BC and POC.

\begin{tabular}{llrr}
\hline type & aerosol type & GEOS-Chem-APM & AeroCom \\
\hline wildland fire & BC & 2.7 & 2.1 \\
& POC & 22.1 & 21.9 \\
& $\mathrm{~S}^{+}$ & 1.2 & 1.4 \\
\hline \multirow{2}{*}{ biofuel } & $\mathrm{BC}$ & 1.6 & 1.3 \\
& $\mathrm{POC}$ & 6.3 & 6.6 \\
& $\mathrm{~S}^{+}$ & 0.2 & 4.8 \\
\hline \multirow{2}{*}{ fossil-fuel } & $\mathrm{BC}$ & 3.0 & 3.0 \\
& $\mathrm{POC}$ & 3.1 & 3.2 \\
& $\mathrm{~S}^{+}$ & 51.1 & 49.5 \\
\hline
\end{tabular}

Table 3. Natural sulfur $\left(\mathrm{S}^{+}\right)$emissions from GEOS-Chem-APM and comparison with AeroCom. Unit: $\mathrm{Tg} \mathrm{yr}^{-1}$

\begin{tabular}{llrr}
\hline & aerosol type & $\begin{array}{r}\text { GEOS-Chem- } \\
\text { APM }\end{array}$ & AeroCom \\
\hline DMS & $\mathrm{S}^{+}$ & 18.6 & 18.2 \\
volcanic, explosive & $\mathrm{S}^{+}$ & 5.9 & 2.0 \\
volcanic, continuous & $\mathrm{S}^{+}$ & 9.0 & 12.6 \\
\hline
\end{tabular}

but a large fraction (up to 50-80\%) (Yu et al., 2012) can become coated on various primary particles in certain regions, particularly in East Asia.

The global annual mean anthropogenic aerosol burden from GEOS-Chem-APM is summarized in Table 4. The modeled aerosol burdens for sulfate, $\mathrm{BC}$ and $\mathrm{POC}$ are all within the range of AeroCom. The anthropogenic fraction of sulfate $(60 \%)$ is within the range of AeroCom, but the fractions of POC $(80 \%)$ and $\mathrm{BC}(100 \%)$ are much higher than that of AeroCom. It should be noted that BC and POC from all biomass burnings are taken as anthropogenic aerosols in this study, while biomass burning in AeroCom is considered both anthropogenic and natural, so the contribution of their optical depths to the total optical depth (both anthropogenic and natural) is higher in this study than those in AeroCom.

Sea salt and mineral dust are the most abundant natural aerosol species. The GEOS-Chem-APM simulated sea salt and dust burdens are also listed in Table 5. It is shown that they are all well within the range of AeroCom, and close to the AeroCom mean values.

As we discussed above, the GEOS-Chem-APM could produce reasonable aerosol burdens in terms of other models. However, it is more important to compare the model performance with observations. In this study, we used several aerosol observational datasets at the surface to validate the simulated aerosol concentrations. The datasets used to validate sulfate concentrations come from three different sources. The first one provides non-sea-salt sulfate concentrations over industrial regions, the Arctic and Subarctic, 
Secondary particle (SP)
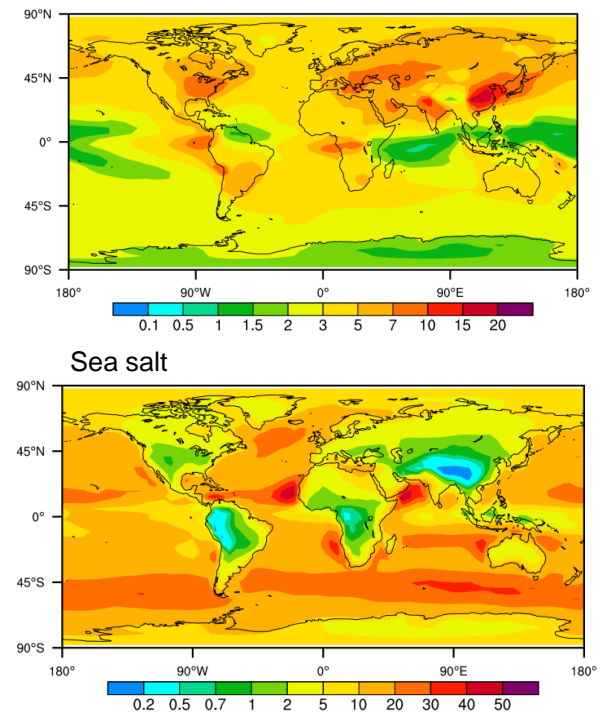

$\mathrm{BC}$

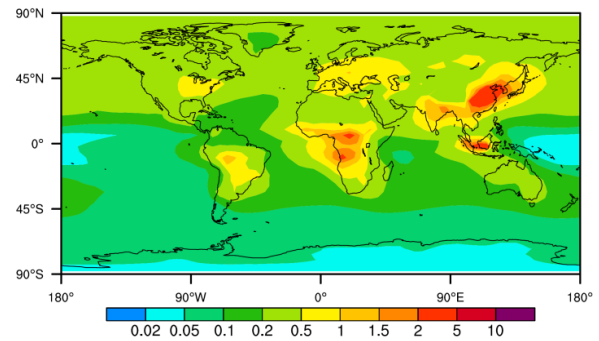

Coated secondary species
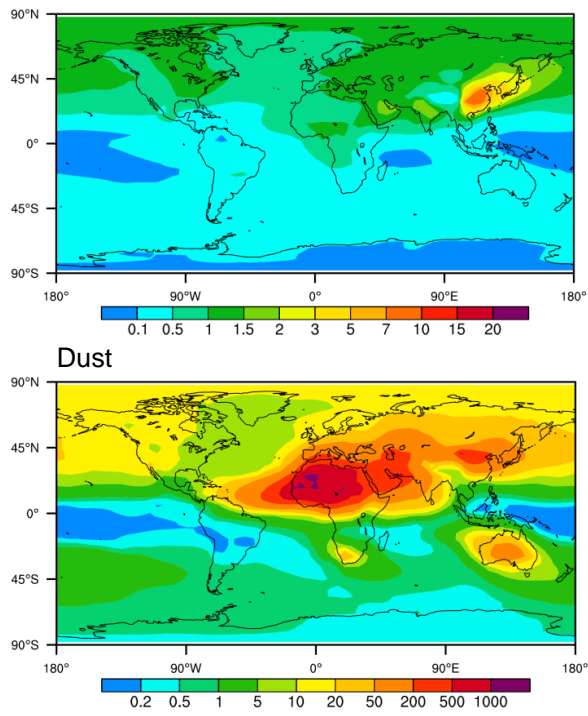

POC

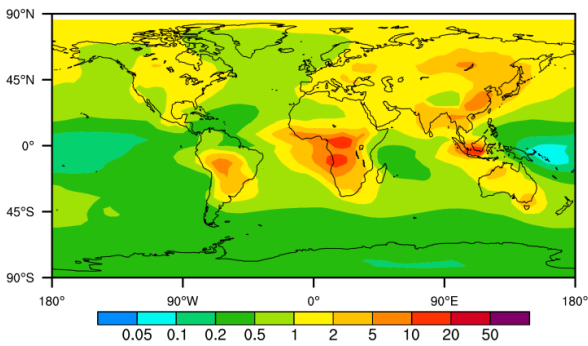

Fig. 1. Modeled annual mean aerosol burden (Unit: $\mathrm{mg} \mathrm{m}^{-2}$ ) from GEOS-Chem-APM model.

Table 4. Global averaged anthropogenic aerosol burden, and its fraction to total aerosol from GEOS-Chem-APM and from AeroCom simulations (Schulz et al., 2006). Please note that the GEOSChem-APM results are for the year 2006, while AeroCom results are for the year 2000 .

\begin{tabular}{lllll}
\hline & \multicolumn{2}{c}{ GEOS-Chem-APM } & \multicolumn{2}{c}{ AeroCom mean and range } \\
\cline { 2 - 5 } & $\begin{array}{l}\text { burden } \\
\left(\mathrm{mg} \mathrm{m}^{-2}\right)\end{array}$ & $\begin{array}{l}\text { anthrop. } \\
\text { S }\end{array}$ & $\begin{array}{l}\text { burden } \\
\left(\mathrm{mg} \mathrm{m}^{-2}\right)\end{array}$ & $\begin{array}{l}\text { anthrop. } \\
\%\end{array}$ \\
\hline Sulfate & 1.92 & $60 \%$ & $2.12(1.34-3.64)$ & $55 \%(41-64 \%)$ \\
POC & 0.82 & $80 \%$ & $1.16(0.77-1.61)$ & $53 \%(46-59 \%)$ \\
BC & 0.22 & $100 \%$ & $0.25(0.16,0.38)$ & \\
\hline
\end{tabular}

$* \mathrm{POC}=\mathrm{POM} / 1.40$

ocean and Antarctic (Chin et al., 1996). The second one includes many measurement sites over North America from IMPROVE (http://vista.cira.colostate.edu/IMPROVE/) in 2006. Additional data (J. M. Prospero and D. L. Savioe, personal communication, 2003) give sulfate concentrations over the ocean and downwind of emission sources. Furthermore, observed BC surface concentrations over the United
Table 5. Global annual mean sea salt and dust burden from GEOSChem-APM simulation and comparison with (Schulz et al., 2006). Unit: $\mathrm{mg} \mathrm{m}^{-2}$.

\begin{tabular}{lrr}
\hline & $\begin{array}{r}\text { GEOS-Chem- } \\
\text { APM }\end{array}$ & $\begin{array}{r}\text { AeroCom mean } \\
\text { and range }\end{array}$ \\
\hline Sea salt & 12.6 & $15.9(7.0,35.7)$ \\
dust & 46.4 & $41(18,59)$ \\
\hline
\end{tabular}

States, Europe and Asia are used for BC comparison (Koch et al., 2009).

A comparison of simulated and observed sulfate concentrations is shown in Fig. 2 (left plot). This scatter plot shows the simulated concentration versus observations for the annual mean. Overall, the simulated sulfate concentrations agree well with the observations, particularly in the United States, where the emission inventory is kept up to date. It is also noted that the simulated concentrations are slightly lower than observations, especially for those sites in remote areas. Although many factors could contribute to the model underestimation, aerosol inter-annual variability could be one of the reasons. 

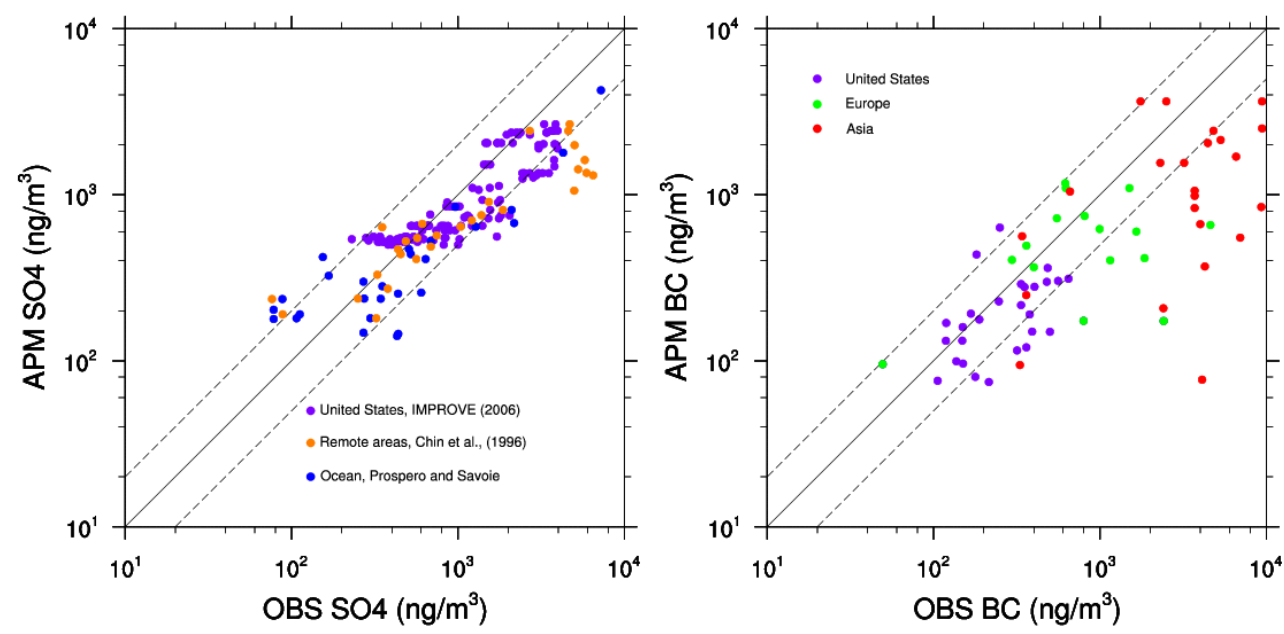

Fig. 2. Comparisons of GEOS-Chem-APM simulated surface sulfate and BC mass concentrations with observational data sets. The observed sulfate concentrations are taken from IMPROVE data set in 2006 (shown in the left), while BC concentrations obtained from Koch et al. (2009) (shown in the right). Three lines indicate 2:1, 1:1 and 1:2.

Figure 2 (right plot) compares simulated BC concentrations with observations. The observed data set for the United States are from the IMPROVE network (1995-2001), while Europe's are from the EMEP network (2002-2003). Some 2006 Asian data are from Zhang et al. (2009), while additional data, mostly from the late 1990s, are referenced in Koch et al. (2007). It is shown that the simulated BC over the United States and Europe are slightly lower than observations, but overall still in good agreement. However, the simulated $\mathrm{BC}$ concentrations are significantly lower than observations in Asia. The discrepancy could be caused by emission inventory as well as parameterizations of various physical processes such as dry and wet scavenging, transport and mixing.

\subsection{Aerosol Optical Depth (AOD)}

Aerosol optical depth (AOD) represents the extinction efficiency of aerosols, including scattering and absorption. Figure 3 shows the simulated annual mean AOD at a wavelength of $550 \mathrm{~nm}$ from GEOS-Chem-APM model and its comparison with AERONET (Holben, 1998), MISR (Martonchik et al., 1998) and MODIS (Kaufman et al., 1997; Remer et al., 2005) satellite retrievals. AEORNET level 2.0 data (cloud-screened and quality-assured) at $500 \mathrm{~nm}$, with at least 8 months of available data, are included in the comparison. MISR (Multi-angle Imaging SpectroRadiometer) AOD data used here is the monthly level-3 product with a resolution of $0.5 \times 0.5^{\circ}$. Annual averaged AOD at $555 \mathrm{~nm}$ (green band) for the year 2006 is applied for comparison with the model simulation. MODIS (Moderate Resolution Imaging SpectroRadiometer) AOD data is taken from the monthly level-3 product from Aqua (MYD08_M3.051) with $1 \times 1^{\circ}$ degree resolution, and combined with deep blue product, which is the separate product specifically retrieved for the AOD over desert regions. The annual averaged AOD at $550 \mathrm{~nm}$ is used for comparison. Overall, the APM model captures the basic features observed in both MISR and MODIS, e.g. the maximum AOD occurs over North and West Africa due to Saharan dust, the maximums over East Asia, India, Europe and North America are mainly due to industrial fossil fuel emission, while the South American peak is due to biomass burning. The simulated spatial distribution and magnitude of AOD are also consistent with AERONET observations. It should be noted that AOD values over Europe and Northern Asia are larger than observations. As stated above the AOD for GEOS-Chem-APM in Fig. 3 is for all sky condition. Yu et al. (2012) showed that AODs in these regions for all sky can be $20-40 \%$ higher than those for clear sky. More detailed description of calculations of AOD and comparison with observations could be found in Yu et al. (2012).

The aerosol absorption optical depth (AAOD) is calculated as $\mathrm{AAOD}=\mathrm{AOD} *(1-\mathrm{SSA})$, where SSA is the single scattering albedo. The spatial pattern of AAOD (top plot of Fig. 4) corresponds to the distribution of the strong absorbing aerosols, including BC and mineral dust. Therefore, high AAOD were found over land, specifically over the Saharan Desert, East Asia, Arabian Peninsula, Australia, South America and North America, etc. The global annual mean AAOD is small (0.002) compared with total AOD (0.15), but absorption in the atmosphere by aerosols does strongly influence the radiation flux and atmospheric vertical profile. In order to compare with AERONET data, we computed the annual mean AAOD for the sites with whole twelve month observational data available in 2006. It is shown (bottom plot of Fig. 4) that the model captures the major regions with high absorption, e.g. North Africa, Arabian Peninsula, India, and Eastern China. However, the modeled AAOD are overall 

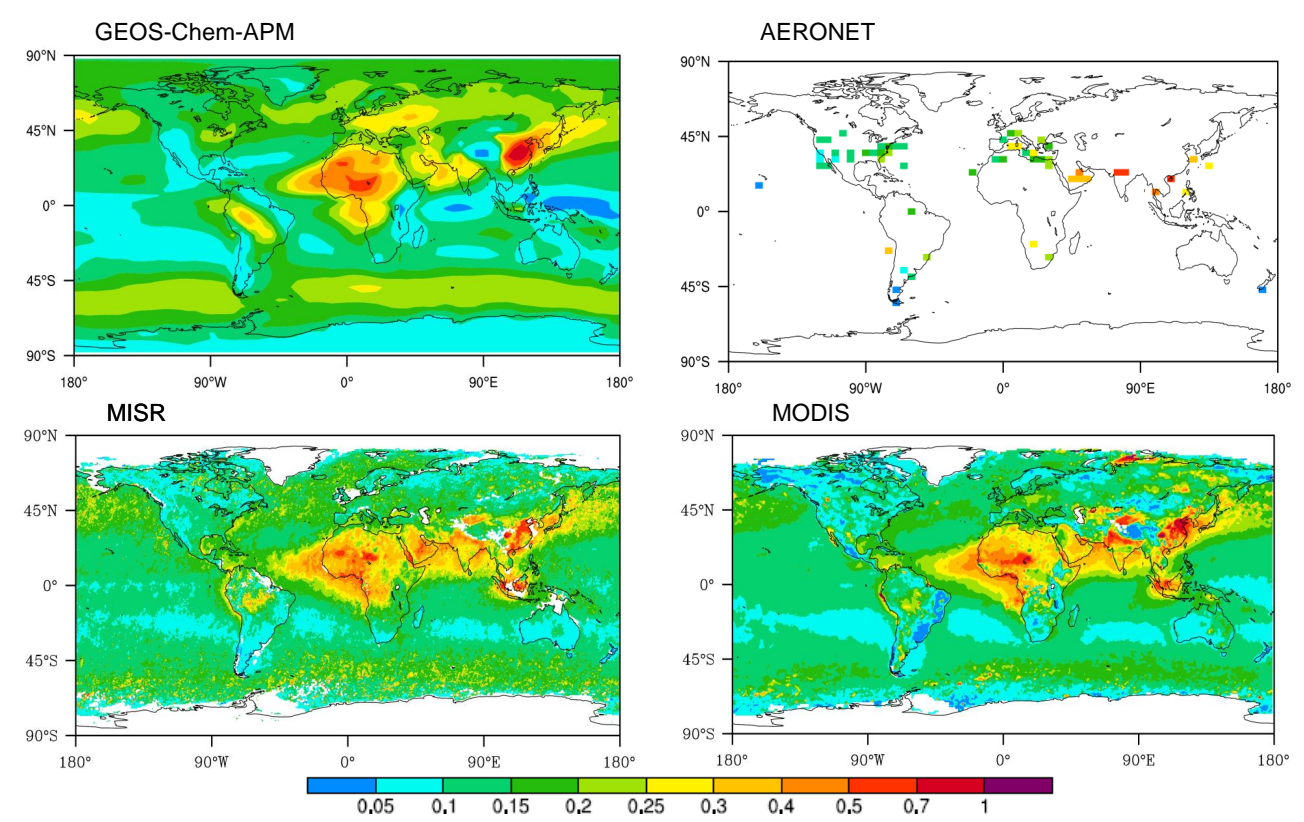

Fig. 3. Annual mean (year 2006) aerosol optical depth (AOD) from GEOS-Chem APM model at $550 \mathrm{~nm}$, AERONET at $500 \mathrm{~nm}$, MISR satellite retrieval at green band, and MODIS retrieved values at $550 \mathrm{~nm}$. The AERONET data are for 1996-2011, v2 level 2, annual averages for each year were used if $>8$ months were present. MODIS AOD includes the values over desert areas from deep blue algorithm on board Aqua.

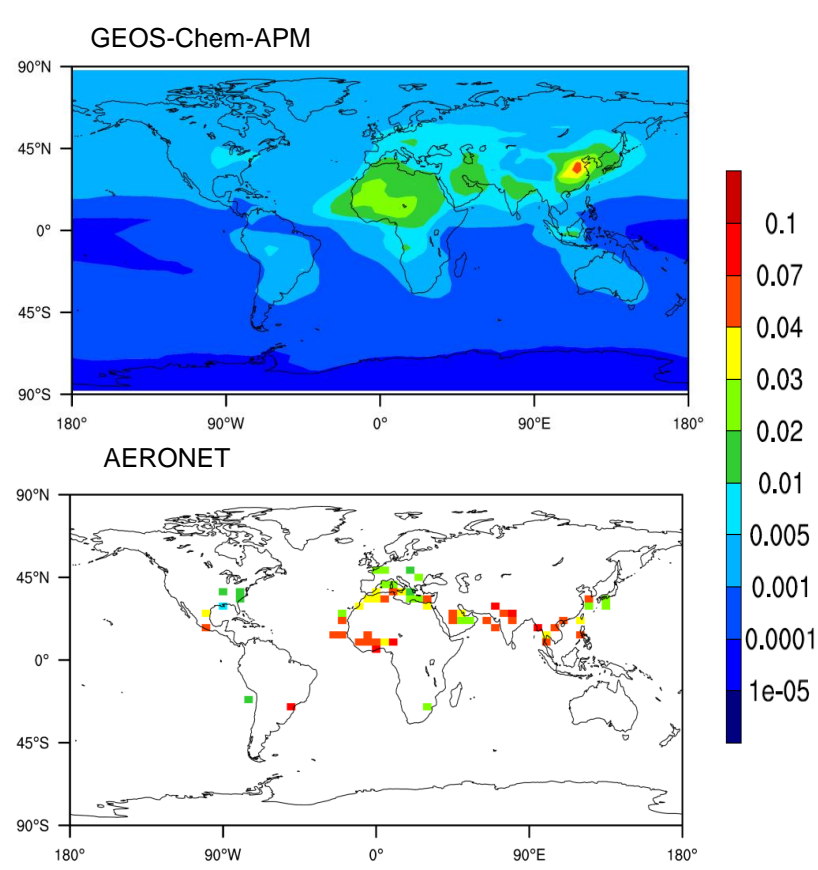

Fig. 4. Annual averaged (year 2006) aerosol absorption optical depth (AAOD) from GEOS-Chem-APM (top) and AERONET observations (bottom) at $550 \mathrm{~nm}$. lower than the observations by a factor of $\sim 2$, which is likely (at least partially) due to the lower modeled BC concentrations as shown in Fig. 2.

The aerosol mixing state in GEOS-Chem-APM is explicitly prognostic (Yu and Luo, 2009). Primary aerosol particles, including sea salt, mineral dust, POC and BC, could be coated by SP once emitted, via the processes of condensation and coagulation. Semi-external mixing is physically more reasonable and consistent with the observations, so the results below are all based on the assumption of semiexternally mixed aerosols. The effect of different mixing states on radiative forcing will be discussed in Sect. 4.

\subsection{Shortwave (SW) DRF by total aerosols}

DRF is defined as the difference between net shortwave flux with and without aerosols. Figure 5 shows the DRF at TOA and surface for clear sky and all sky (cloud included). The results shown here include DRF from both natural and anthropogenic aerosols. Over clear sky condition, it is shown that the overall effect of aerosols on the Earth-atmosphere system is cooling everywhere. The strong cooling occurs over East Asia, Europe and North America due to the large amount of anthropogenic emissions, while over the Southern Ocean, North Atlantic and North Pacific it is due to high sea salt production. At the surface, DRF is always negative, indicating strong cooling induced by total aerosols. The stronger cooling areas are consistent with the cooling at TOA since aerosol particles scatter a large amount of incoming solar radiation, 

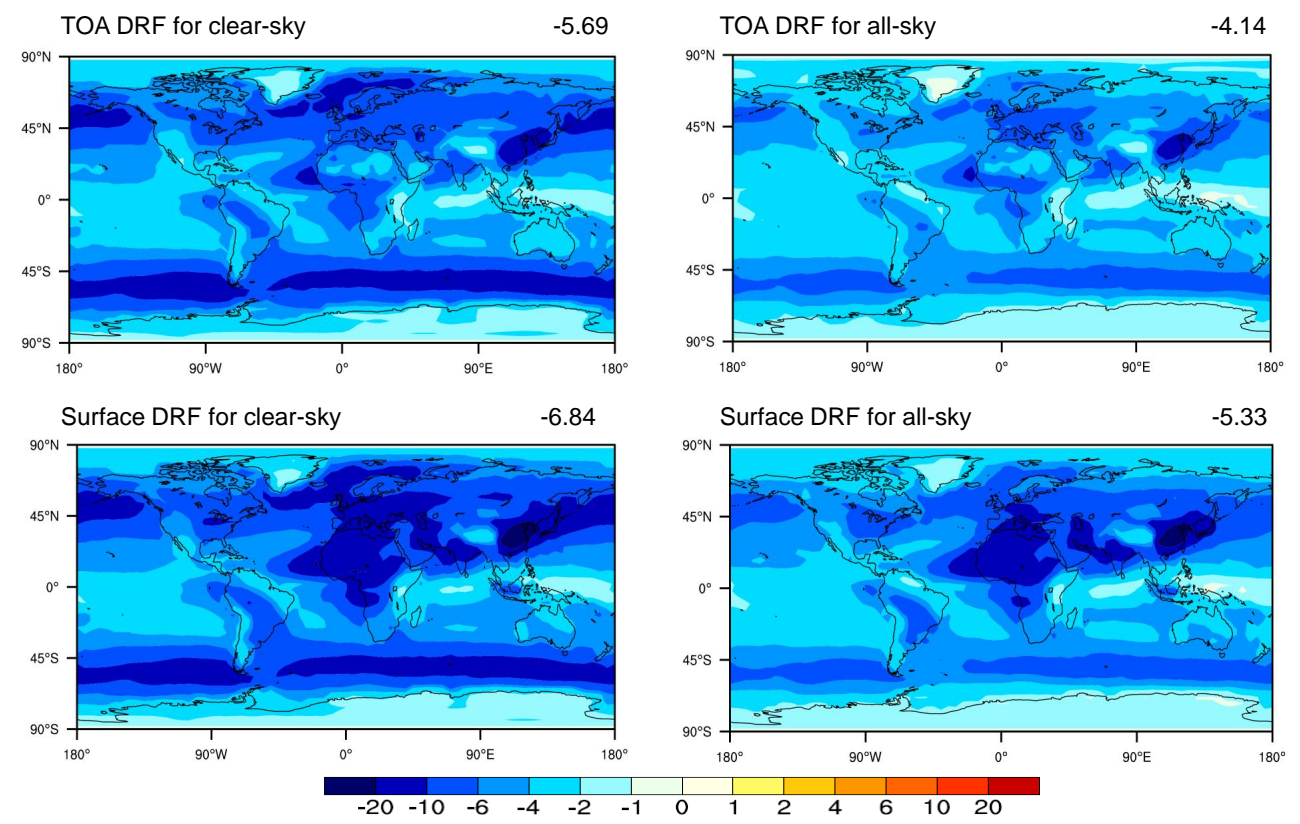

Fig. 5. Total aerosol DRF from all aerosols at TOA and surface for both clear sky and all sky. Unit: $\mathrm{W} \mathrm{m}^{-2}$.

so less solar radiation reaches the surface. In addition, there is a strong cooling found over Africa, because the mineral dust particles absorb solar radiation which reduces the downward flux. For all sky condition, aerosol DRF decreases compared to clear sky conditions for both TOA and the surface because of the cloud effect.

It is shown that the global annual mean SW DRF due to total aerosols over all sky is -4.1 and $-5.3 \mathrm{~W} \mathrm{~m}^{-2}$ at TOA and the surface, respectively. The magnitude of surface forcing is much larger than the TOA forcing because of the strong absorption of solar radiation by the atmosphere $\left(1.2 \mathrm{~W} \mathrm{~m}^{-2}\right)$. The change in atmospheric flux equals TOA forcing minus surface forcing. Yu et al. (2006) assessed the SW DRF for clear sky based on the satellite retrieved AOD. They obtained an estimate of clear-sky DRF over the ocean as $-5.5 \pm 0.2 \mathrm{~W} \mathrm{~m}^{-2}$ (median \pm standard error) at the TOA, and $-8.8 \pm 0.7 \mathrm{~W} \mathrm{~m}^{-2}$ at surface. The estimated DRF over land is $-4.9 \pm 0.7 \mathrm{~W} \mathrm{~m}^{-2}$ at the TOA, and $-11.8 \pm 1.9 \mathrm{~W} \mathrm{~m}^{-2}$ at surface. Compared with the above study, the global annual mean SW DRF for clear sky in our study is calculated as $-5.7 \mathrm{~W} \mathrm{~m}^{-2}$ at TOA, which indicates a relatively strong cooling. In contrast, the DRF at surface $\left(-6.8 \mathrm{~W} \mathrm{~m}^{-2}\right)$ shows a relatively weak cooling. Therefore it is possible that our model underestimates the atmospheric absorption. A model study of Liu et al. (2007) calculated the global annual mean of total aerosol DRF at TOA for clear sky as $-4.3,-4.0$, and $-4.1 \mathrm{~W} \mathrm{~m}^{-2}$ depending on the different meteorology, while the corresponding DRF at surface as $-6.3,-6.0$, and $-6.2 \mathrm{~W} \mathrm{~m}^{-2}$. The atmospheric DRF is thus calculated to be about $2 \mathrm{~W} \mathrm{~m}^{-2}$, which is higher than our calculations.

\subsection{Longwave (LW) radiative forcing by aerosols}

We also examine the aerosol longwave radiative forcing. Since the LW radiative forcing is generally minor for smaller particles ( $\mathrm{Li}$ et al., 2002) and sea salt (Ma et al., 2008), only radiative forcing by mineral dust is investigated here. As shown in Fig. 6, LW radiative forcing at TOA is positive (warming), with the maximum around $1 \mathrm{~W} \mathrm{~m}^{-2}$ annual average over the Saharan Desert. Globally, the averaged LW radiative forcing (mineral dust) is negligible $\left(+0.1 \mathrm{~W} \mathrm{~m}^{-2}\right)$ compared to the SW radiative forcing $\left(-4.1 \mathrm{~W} \mathrm{~m}^{-2}\right)$, so we will focus on SW radiative forcing in the next sections.

\section{Anthropogenic aerosol DRF and uncertainties}

In the last section, we presented the GEOS-Chem-APM simulated aerosol concentrations and comparisons with observational datasets, AOD and DRF for total aerosol (both anthropogenic and natural). Compared to the total aerosols, anthropogenic aerosols have been believed to exhibit a more important impact on climate change since the industrial revolution. According to the IPCC AR4 report, the estimation of global mean DRF by anthropogenic aerosols still remains a wide range (from -0.1 to $-0.9 \mathrm{~W} \mathrm{~m}^{-2}$ ), so further studies are necessary to more accurately estimate DRF due to anthropogenic aerosols. In this section, we mainly focus on the estimation of DRF due to anthropogenic aerosols. We also discuss the uncertainties of aerosol size and density, surface albedo and mixing state on the DRF. All experiments and their descriptions are listed in Table 6. 
Table 6. Description of base run and sensitivity runs.

\begin{tabular}{|c|c|}
\hline name & Model description \\
\hline Base run & GEOS-Chem-APM, coating \\
\hline BCOCsize & $\mathrm{BC}$ and $\mathrm{OC}$ size reduced $50 \%$ \\
\hline BCden 1.2 & $\begin{array}{l}\mathrm{BC} \text { density as } 1.2 \mathrm{~g} \mathrm{~cm}^{-3} \text {, rather than } \\
1.8 \mathrm{~g} \mathrm{~cm}^{-3} \text { as in base run }\end{array}$ \\
\hline NoCoat & GEOS-Chem-APM, without coating on BC \\
\hline
\end{tabular}

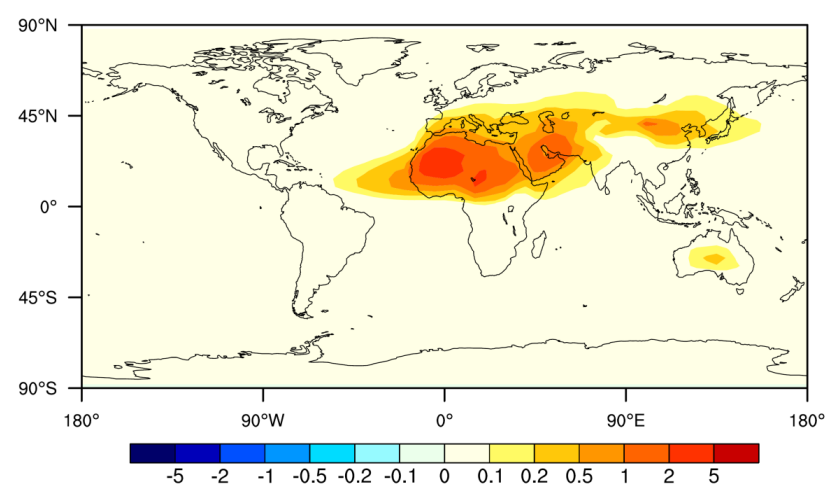

Fig. 6. Longwave radiative forcing at TOA induced by mineral dust. Unit: $\mathrm{W} \mathrm{m}^{-2}$.

\subsection{DRF induced by anthropogenic aerosols}

Based on the experiments listed in Table 6, we conducted the second set of experiments to obtain the DRF induced by anthropogenic aerosols, but with the emissions from anthropogenic aerosol emissions turned off. The differences of DRF between the first set of experiments (total aerosols) and the second set (natural aerosols) will be taken as the DRF from anthropogenic aerosols.

Figure 7 presents the annual mean anthropogenic aerosol DRF at TOA, atmosphere, and surface for all sky. It is shown that anthropogenic aerosols cause a net cooling (negative DRF at TOA) in most regions, except a net warming (positive DRF at TOA) over South America, which should be attributed to BC as we treat all biomass burning as anthropogenic source in the present study. DRF at TOA is significantly higher in Asia than other areas most likely because of the substantial increase in industrial emissions over the last decade. Atmospheric absorption from anthropogenic aerosols, mainly due to BC particles, is linked to fossil fuel emission and biomass burning. As more incoming solar radiation was absorbed by the atmosphere, less solar radiation reaches the surface. Thus, DRF at surface becomes more negative. The magnitude of the global mean anthropogenic aerosol DRF based on GEOS-Chem-APM is $-0.41,0.72$, $-1.13 \mathrm{~W} \mathrm{~m}^{-2}$ at TOA, atmosphere and surface, respectively.

Table 7 summarizes the basic model characterization and results in GEOS-Chem-APM and AeroCom. Aerosol size distributions are represented based on a modal approach in
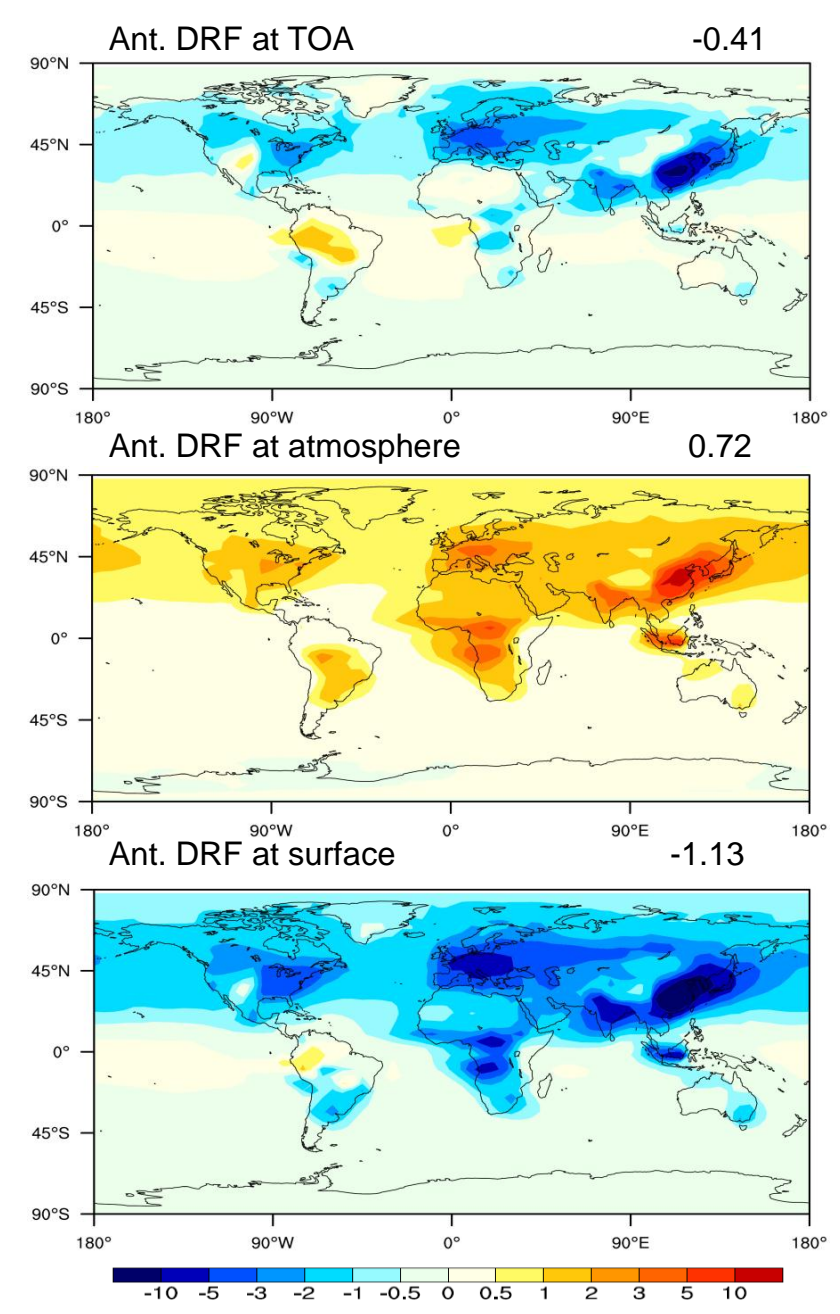

Fig. 7. Annual mean anthropogenic aerosol DRF at TOA, atmosphere and surface for all sky. The global mean values are shown on the right top of each plot. Unit: $\mathrm{W} \mathrm{m}^{-2}$.

several models, but represented with a bin approach in most models. Much higher bin resolution is used in the GEOSChem-APM model, so that the aerosol size distribution could be simulated more realistically. It is also noted that most models treat aerosol particles as externally mixed. GEOSChem-APM is designed to explicitly predict the spatialtemporal variations in the degree of particle mixing, i.e. being semi-externally mixed. The DRF values simulated in GEOS-Chem-APM are within the ranges generated by the various models, with a slightly stronger cooling in the earthatmosphere system than most models. The atmospheric forcing from GEOS-Chem-APM is in the lower part of the range $(0.61,1.14)$, possibly because of the values of BC size and density applied in the models. We will examine the DRF by changing the $\mathrm{BC}$ size and density in the next section. The comparisons of aerosol burden, optical depth $\left(\tau_{\text {aer }}\right)$ and normalized RF per unit $\tau_{\text {aer }}$ are also listed in Table 7 . These 
Table 7. Simulations from GEOS-Chem-APM and AeroCom models, and results in IPCC (2007) for anthropogenic aerosol burden, optical depth $\left(\tau_{\text {aer }}\right)$, the normalized RF per unit optical depth (NRF) for clear-sky. The aerosol direct raidative forcing at top of atmosphere (TOA) and surface and atmoshphere are given for al-sky conditions. Aerosol model information (bin or modal) and mixing state are also given in the table. The results from AeroCom are taken from Table 5 in Schulz et al. (2006).

\begin{tabular}{|c|c|c|c|c|c|c|c|c|c|c|c|}
\hline Model & $\begin{array}{l}\text { Burden } \\
\mathrm{mg} \mathrm{m}^{-2}\end{array}$ & $\tau_{\mathrm{aer}}$ & $\begin{array}{r}\mathrm{NRF} \\
\text { clear-sky } \\
\mathrm{W} \mathrm{m}^{-2} \tau_{\mathrm{aer}}^{-1} \\
\end{array}$ & $\begin{array}{r}\mathrm{RF} \text { toa } \\
\text { clear sky } \\
\mathrm{W} \mathrm{m}^{-2}\end{array}$ & 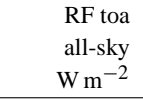 & all-sky & $\begin{array}{l}\text { Atmos. } \\
\text { forcing } \\
\mathrm{W} \mathrm{m}^{-2}\end{array}$ & all-sky & $\begin{array}{l}\text { Surface } \\
\text { forcing } \\
\mathrm{W} \mathrm{m}^{-2}\end{array}$ & $\begin{array}{l}\text { Aerosol } \\
\text { model } \\
\text { information }\end{array}$ & $\begin{array}{l}\text { Aerosol } \\
\text { mixing }\end{array}$ \\
\hline UMI & 4.0 & 0.028 & -29 & -0.80 & -0.41 & & 0.84 & & -1.24 & $\begin{array}{l}13 \text { bins } 3 \mathrm{SO}_{4}, \\
1 \mathrm{POC}, 1 \mathrm{BC}, 4 \mathrm{DU}, 4 \mathrm{SS}\end{array}$ & ext \\
\hline UIO_CTM & 3.0 & 0.026 & -33 & -0.85 & -0.34 & & 0.61 & & -0.95 & $\begin{array}{l}25 \text { bins } 8 \mathrm{DU}, 8 \mathrm{SS} \\
4 \mathrm{BC}, 4 \mathrm{POC}, 1 \mathrm{SO}_{4}\end{array}$ & $\begin{array}{l}\text { ext except bio } \\
\text { burning }\end{array}$ \\
\hline LOA & 5.3 & 0.046 & -18 & -0.80 & -0.35 & & 1.14 & & -1.49 & $\begin{array}{l}16 \text { bins } 2 \mathrm{DU}, 11 \mathrm{SS} \\
1 \mathrm{BC}, 1 \mathrm{POC}, 1 \mathrm{SO}_{4}\end{array}$ & ext \\
\hline LSCE & 4.8 & 0.033 & -29 & -0.94 & -0.28 & & 0.66 & & -0.93 & 5 modes & ext \\
\hline GISS & 2.8 & 0.014 & -21 & -0.29 & -0.11 & & 0.79 & & -0.81 & $\begin{array}{l}13 \text { bins } 2 \mathrm{SS}, 4 \mathrm{DU} \\
1 \mathrm{BC}, 1 \mathrm{SO} 4,4 \mathrm{DU} / \mathrm{SO}_{4}\end{array}$ & ext \\
\hline UIO_GCM & 2.8 & 0.017 & & & -0.01 & & 0.84 & & -0.84 & 12 modes & 4 ext, 8 int \\
\hline SPRINTARS & 3.2 & 0.036 & -10 & -0.35 & +0.04 & & 0.96 & & -0.91 & $\begin{array}{l}17 \text { bins } 10 \mathrm{DU}, 4 \mathrm{SS}, 1 \mathrm{BC} \text {, } \\
1 \mathrm{BCPOC}, 1 \mathrm{SO}_{4}\end{array}$ & ext \\
\hline ULAQ & 3.7 & 0.030 & -26 & -0.79 & -0.24 & & & & & $\begin{array}{l}41 \text { bins } 7 \mathrm{DU}, 9 \mathrm{SS}, \\
5 \mathrm{BC}, 5 \mathrm{POC}, 15 \mathrm{SO}_{4}\end{array}$ & ext \\
\hline Average & 3.8 & 0.029 & -23 & -0.68 & -0.22 & & 0.82 & & -1.02 & & \\
\hline Stddev & 0.9 & 0.010 & 7 & 0.24 & 0.16 & & 0.17 & & 0.23 & & \\
\hline IPCC & & & & & {$[-0.1,-0.9]$} & & & & & & \\
\hline GEOS-Chem -APM & 4.5 & 0.026 & -23 & -0.59 & -0.41 & & 0.71 & & -1.13 & $\begin{array}{l}75 \text { bins and } 8 \text { modes } 40 \mathrm{SO}_{4} \text {, } \\
20 \mathrm{SS}, 15 \mathrm{DU}, 4 \text { modes } \\
\text { for BC and } 4 \text { modes for POC }\end{array}$ & Semi-ext \\
\hline
\end{tabular}

results all agree well with the AeroCom models. The difference between DRF for clear sky and all sky conditions in GEOS-Chem-APM is slightly lower than the differences in most models, indicating that the effect of clouds in GEOSChem-APM is relatively weak. More work associated with parameterizations of cloud microphysics (cloud cover, cloud radius, liquid and ice water content, etc.) need to be carried out in the future.

Zonal mean DRF (Fig. 8) shows clearly that most of the anthropogenic aerosol DRF is most prominent in the Northern Hemisphere, particularly over major industrial regions. The largest DRF occurs around $30^{\circ} \mathrm{N}$, with the annual mean values up to $-1.4,1.9$ and $-3.3 \mathrm{~W} \mathrm{~m}^{-2}$ at TOA, atmosphere and surface, respectively. In contrast, anthropogenic DRF from $50^{\circ} \mathrm{S}$ to $90^{\circ} \mathrm{S}$ is trivial.

The seasonal variability of anthropogenic aerosol DRF is shown in Fig. 9. We see that the DRF at TOA shows more strongly cooling in MAM (March, April and May) and JJA (June, July, and August) than in SON (September, October and November) and DJF (December, January and February) due to low oxidation concentrations and oxidation rates in the latter two seasons (Ma and von Salzen, 2006) in the Northern Hemisphere. The global mean DRF (shown in Fig. 10) is affected to a greater extent by oxidation rates in the Northern Hemisphere than the Southern Hemisphere due to the larger contributions of anthropogenic aerosol particles and their precursors in the Northern Hemisphere. The biomass burning-induced positive DRF at TOA over the Amazon also shows significant seasonality, with the largest positive DRF in SON (dry season). It is also noted that atmospheric absorp-

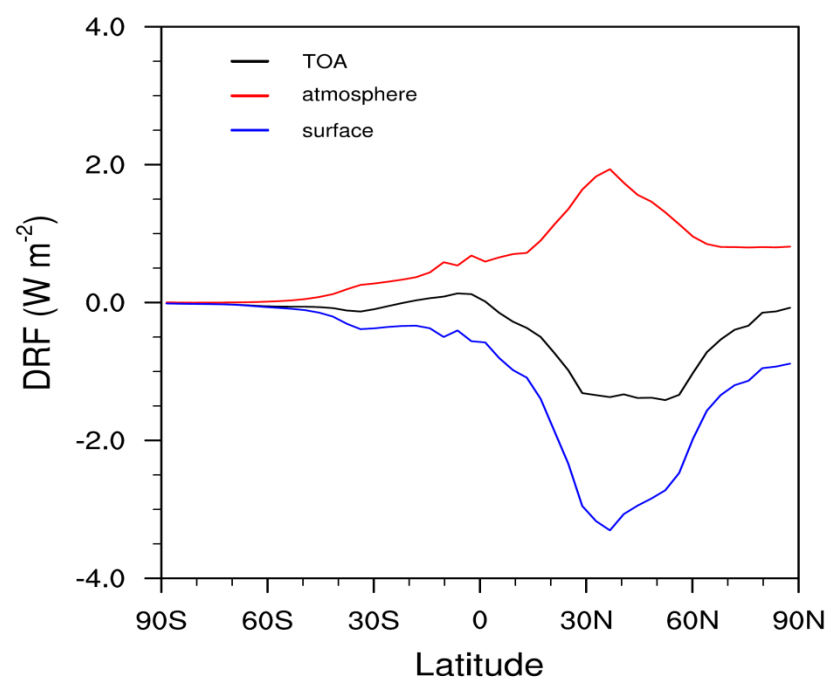

Fig. 8. Zonal mean anthropogenic aerosol DRF at TOA, atmosphere and surface for all sky. Unit: $\mathrm{W} \mathrm{m}^{-2}$.

tion is stronger in MAM and JJA, especially over the high latitudes in Northern Hemisphere, and is possibly associated with the strong transport and frequent convection in these seasons. The DRF at surface, therefore, becomes more negative over these regions in MAM and JJA. Figure 10 shows the global averaged monthly mean radiative forcing in 2006, with the strongest cooling at TOA in April $\left(-0.55 \mathrm{~W} \mathrm{~m}^{-2}\right)$ and the weakest forcing in August $\left(-0.18 \mathrm{~W} \mathrm{~m}^{-2}\right)$. The latter is caused by warming in some regions, e.g. Asia, due to 

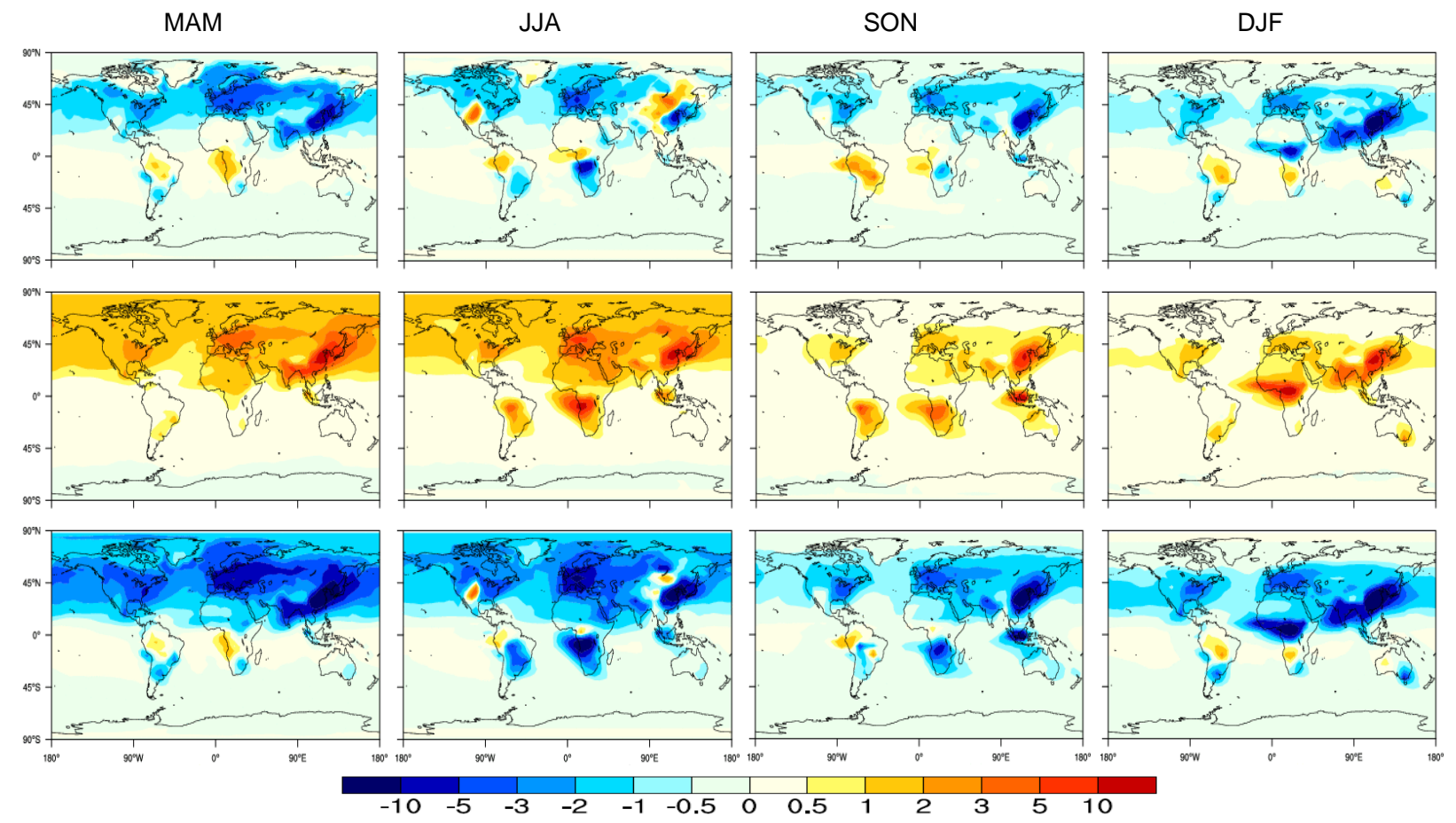

Fig. 9. Annual mean anthropogenic aerosol DRF at TOA (top), atmosphere (middle) and surface (bottom) for all sky in MAM, JJA, SON and DJF. Unit: $\mathrm{W} \mathrm{m}^{-2}$.

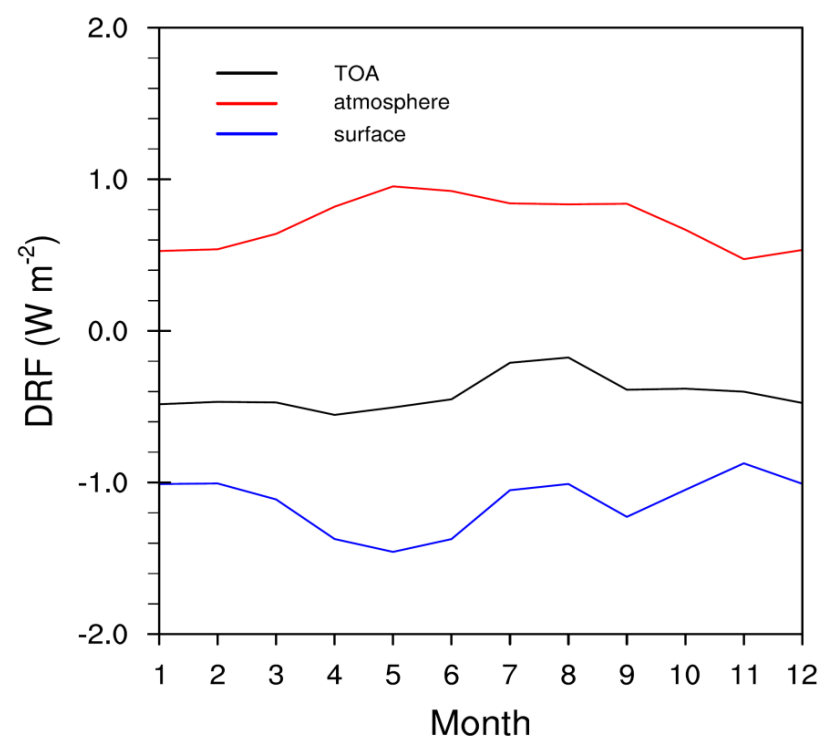

Fig. 10. Monthly mean anthropogenic aerosol DRF at TOA, atmosphere and surface for all sky. Unit: $\mathrm{W} \mathrm{m}^{-2}$.

enhanced absorption by coating although there are cooling in most regions of the Northern Hemisphere in summer season, as shown in Fig. 9. The strongest atmospheric absorption occurs in May $\left(0.95 \mathrm{~W} \mathrm{~m}^{-2}\right)$ and weakest in November $\left(0.47 \mathrm{~W} \mathrm{~m}^{-2}\right)$, while the corresponding DRF at the surface is $-1.46 \mathrm{~W} \mathrm{~m}^{-2}$ and in $-0.87 \mathrm{~W} \mathrm{~m}^{-2}$.

\subsection{Uncertainties of anthropogenic aerosol DRF}

As discussed, quite a few factors could cause the bias of the simulated DRF. The GEOS-Chem is driven by the assimilated meteorological fields, which provides the relatively accurate meteorology into the model compared to the model-produced meteorology. In the study, we also employed the updated aerosol refractive indices for various components to reduce the uncertainties. In addition we applied the waveband-variable surface albedo from MODIS satellite retrievals to constrain the uncertainties. In this section, we will examine the uncertainties in our results from other factors including particle size, density and the mixing state by conducting a number of sensitivity experiments specified in Table 6 .

\subsubsection{BC and POC particle size}

In this study, SP, sea salt and mineral dust particle size distribution are prognostic by using 40,20 and 15 size bins. The tracers for POC and BC are not treated as size resolved, thus the particle size are prescribed according to observations or simple assumptions. The prescribed particle size of $\mathrm{BC}$ remains a large range, e.g. In AeroCom models $\mathrm{BC}$ size ranges from 0.01 to $0.8 \mu \mathrm{m}$ in mass median diameter (Koch et al., 2009). Dentener et al. (2006) recommended a mode 

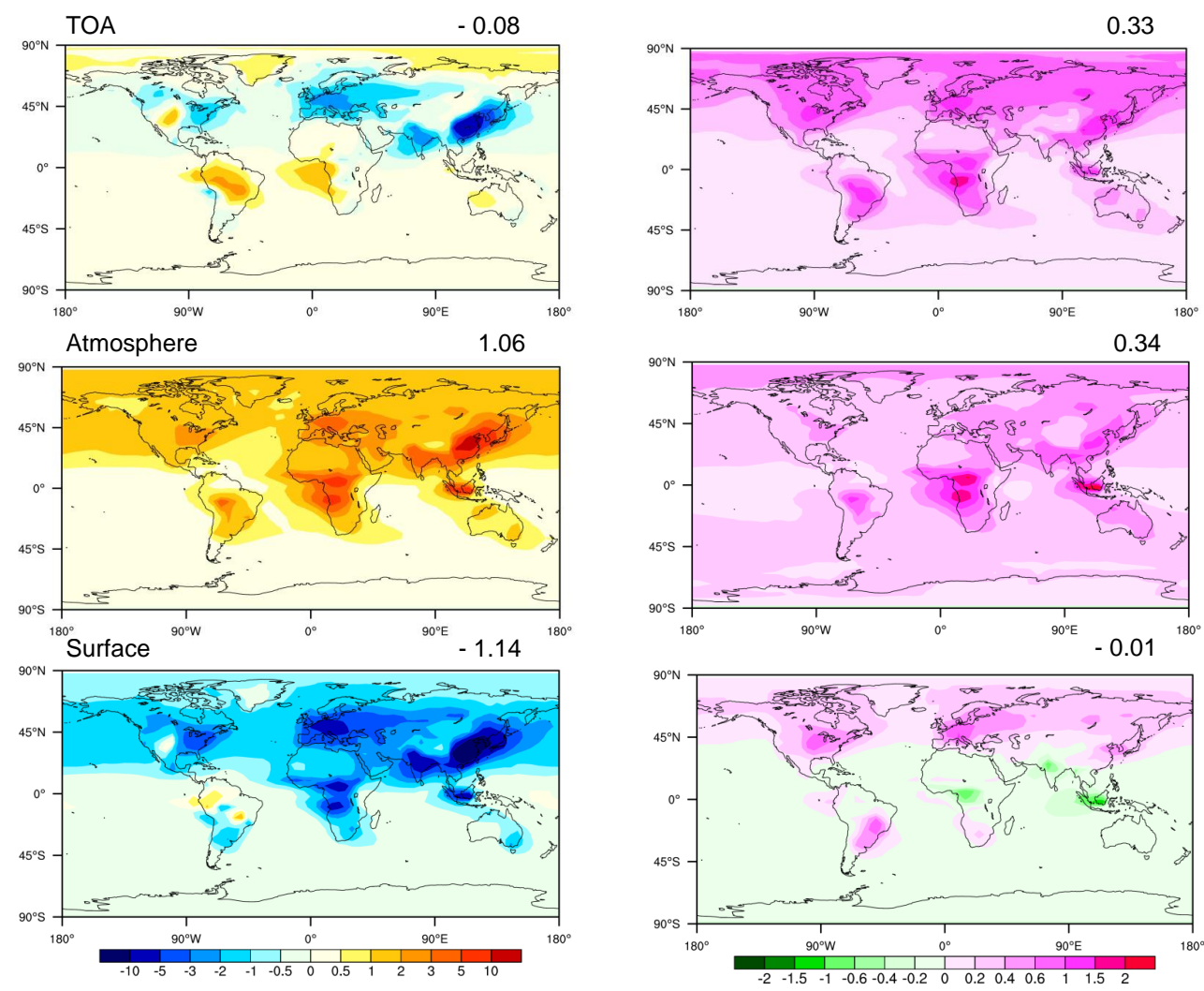

Fig. 11. The simulated aerosol DRF (left column) in the experiment BCOCsize and its change relative to the base run (right column) at TOA, atmosphere and surface for all sky condition. The value in each plot shows the global annual mean. The positive (negative) in the left column represents that the DRF is positive (negative), while in the right column represents that change of DRF (sensitivity experiments base experiment). Unit: $\mathrm{W} \mathrm{m}^{-2}$.

diameter of $30 \mathrm{~nm}$, a standard deviation of 1.8 for fossil fuel $\mathrm{BC}\left(\mathrm{BC}_{\mathrm{FF}}\right)$, a mode diameter of $80 \mathrm{~nm}$ and a standard deviation of 1.8 for biofuel and biomass burning $\left(\mathrm{BC}_{\mathrm{BB}}\right)$. The mode diameters recommended by Dentener et al. (2006) appears to be much smaller than those observed (Eastwood, 2008; Weimer et al., 2009). The study of Yu and Luo (2009) suggested that the large values, i.e. number median diameter of $60 \mathrm{~nm}$ and $150 \mathrm{~nm}$ for $\mathrm{BC}_{\mathrm{FF}}$ and $\mathrm{BC}_{\mathrm{BB}}$, should be used to properly predict the contribution of $\mathrm{BC}$ to the number concentration of total particles.

To explore the effect of $\mathrm{BC}$ and $\mathrm{POC}$ particle size on the anthropogenic aerosol DRF in the study, we conducted a pair of experiments in which the size of BC and POC will be reduced to the half of the original size (experiment BCOCsize in Table 6). The DRF (left column) and its change (right column) relative to the base run at TOA, atmosphere and surface for all-sky condition are shown in Fig. 11. It is shown that in the experiment $\mathrm{BCOCsize,} \mathrm{i.e.} \mathrm{if} \mathrm{BC}$ and $\mathrm{POC}$ particles become smaller, atmospheric forcing increases $\left(0.34 \mathrm{~W} \mathrm{~m}^{-2}\right)$ as the atmospheric absorption enhances for the smaller core (BC) particles (Bond et al., 2006). Although smaller POC particles scatter more solar radiation, there is much weaker scattering from SP particles due to the fact that more SP par- ticles are coated on $\mathrm{BC}$ particles. Therefore, the overall effect is that aerosols scatter less solar radiation back to the space, so the DRF at TOA is less negative $\left(-0.08 \mathrm{~W} \mathrm{~m}^{-2}\right)$. In contrast, reducing the particle size of $\mathrm{BC}$ and $\mathrm{POC}$ will not cause any significant change to the DRF at surface, as aerosols scatter less solar radiation back to the space but absorb more solar radiation in the atmosphere.

\subsubsection{Density of $\mathrm{BC}$}

The density of BC remains large uncertainty as well, i.e. BC density ranges from $1.0 \mathrm{~g} \mathrm{~cm}^{-3}$ to $2.0 \mathrm{~g} \mathrm{~cm}^{-3}$ among AeroCom models. Bond et al. (2006) reviewed measurements and recommended that the density of light absorption BC would be $1.7-1.9 \mathrm{~g} \mathrm{~cm}^{-3}$, while the use of $1.0 \mathrm{~g} \mathrm{~cm}^{-3}$ should be abandoned. The density of $\mathrm{BC}$ used in the model will influence the predicted $\mathrm{BC}$ number concentration and, subsequently, AOD and DRF.

We launched a run (BCden1.2) in which the density of BC is equal to $1.2 \mathrm{~g} \mathrm{~cm}^{-3}$, rather than $1.8 \mathrm{~g} \mathrm{~cm}^{-3}$ as in the base run. The DRF and its change relative to the base run are presented in Fig. 12. We can see that atmospheric absorption increases $\left(0.47 \mathrm{~W} \mathrm{~m}^{-2}\right)$ if a smaller density $\left(1.2 \mathrm{~g} \mathrm{~cm}^{-3}\right)$ is 

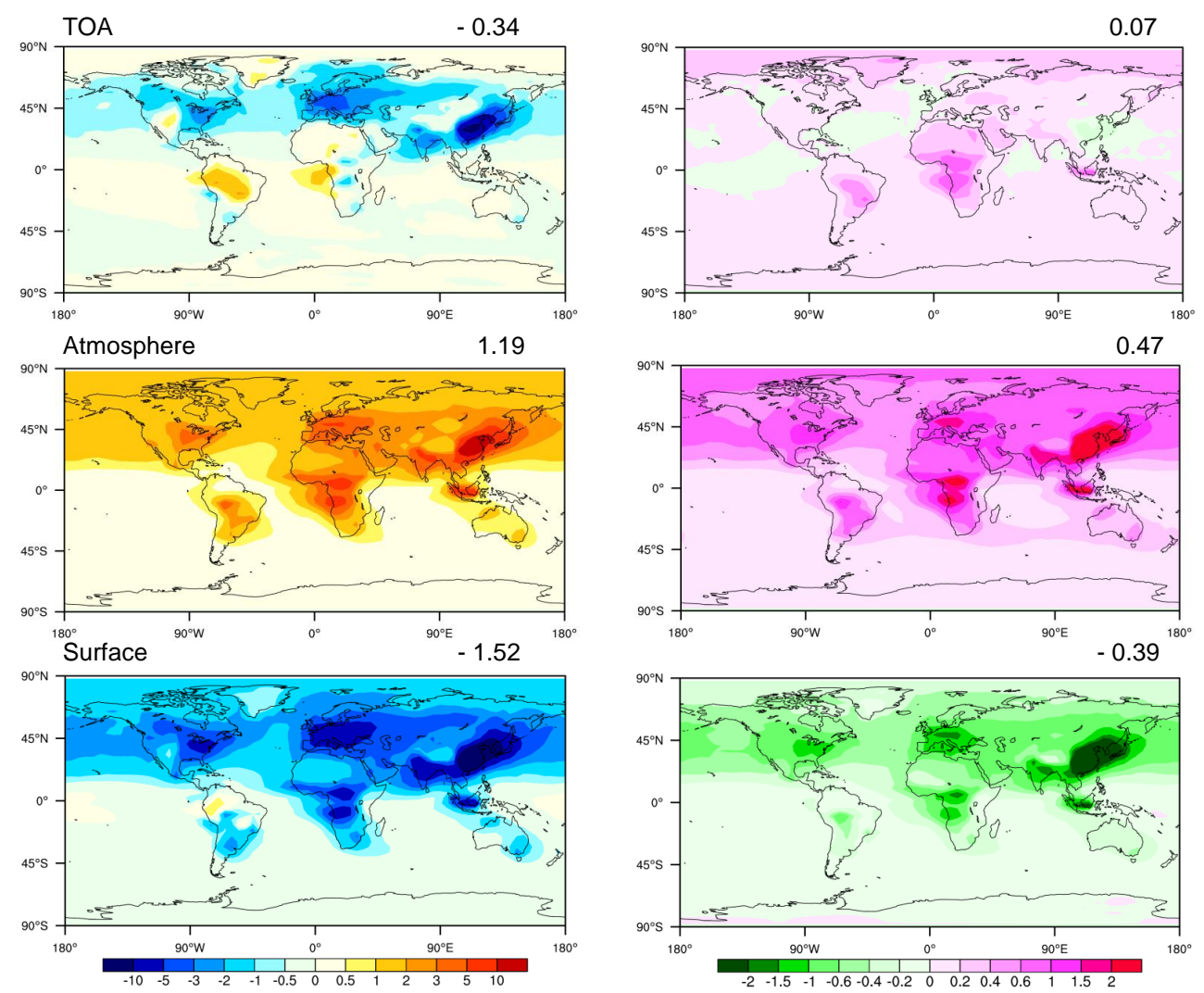

Fig. 12. Same as Fig. 11 but for the results from the experiment (BCden1.2).

applied, since there will be more $\mathrm{BC}$ particles and, thus a higher AAOD and atmospheric absorption. It is noted that the most significant change mainly occurs in the BC source regions and the high latitudes in the Northern Hemisphere due to transport of $\mathrm{BC}$ particles to the region, DRF at TOA only changes a little $\left(0.07 \mathrm{~W} \mathrm{~m}^{-2}\right)$, but the DRF at surface becomes more negative $\left(-1.52 \mathrm{~W} \mathrm{~m}^{-2}\right)$ due to stronger atmospheric absorption. Therefore, using a different density of BC will not cause a significant change of DRF at TOA, but it does change the atmospheric vertical profile significantly.

\subsubsection{Aerosol mixing state}

Previous global models often assumed aerosol particles to be externally mixed (as shown in Table 7), in which the chemical components occur as independent particles. In contrast, some studies assume aerosols to be internally mixed, i.e. component mixed in each individual particle. Observations indicate that soluble aerosol components, such as sulfate, hydrophilic organics, ammonia and nitrate are often wellmixed, but hydrophobic BC particles are rarely well-mixed with other particles. Instead, BC particles will serve as a concentric core on which the hygroscopic particles condense and coagulate. This core-shell coating mixture (i.e. semi-external mixing) has been supported by observations and simulations, e.g. Jacobson (2000) used a global model which accounts for a wide range of atmospheric aerosol processes (i.e. condensation, coagulation, and nucleation), and found that, within five days, more than $60 \%$ of the BC's mass obtained a nonBC coating.

Earlier studies found that coating strongly affects the optical and microphysical properties of $\mathrm{BC}$, e.g. amplification factors of 1.8 to 2.1 due to absorption compared to the external mixed BC (Schnaiter, 2005). Jacobson (2001) estimated the radiative forcing of the $\mathrm{BC}$ for external and semi-external mixing as $0.27 \mathrm{~W} \mathrm{~m}^{-2}$ and $0.54 \mathrm{~W} \mathrm{~m}^{-2}$, respectively.

The GEOS-Chem-APM model has been designed to explicitly predict the spatiotemporal variations in the degree of particle mixing. Compared with the externally-mixed aerosol, the resulting radiative forcing could be quite different. To examine the effect of mixing state on DRF due to anthropogenic aerosols, a pair of experiments (NoCoat) were conducted, which were based on the base experiments but assumed the aerosols as external mixed, i.e. no coating is taken into accounted. The DRF and its change are shown in Fig. 13. It is evident that atmospheric absorption decreases $0.29 \mathrm{~W} \mathrm{~m}^{-2}$, while the DRF at TOA decreases $0.20 \mathrm{~W} \mathrm{~m}^{-2}$ compared with the base experiment. This is because the aerosol particles scatter more solar radiation due to weak atmospheric absorption without coating. The major 

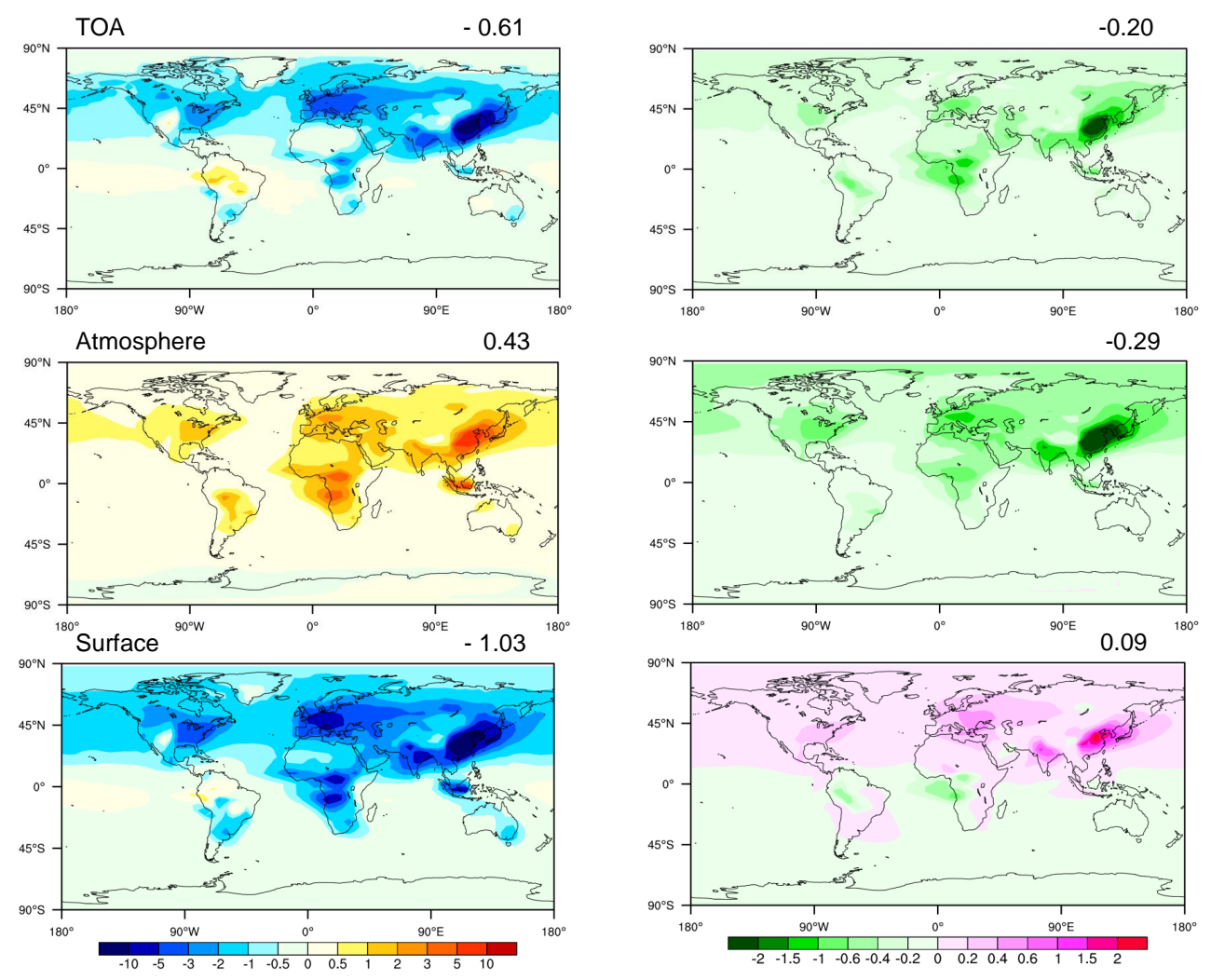

Fig. 13. Same as Fig. 11 but for the experiment NoCoat.

differences occur in the Northern Hemisphere, specifically over East Asia, Central Africa, eastern United States and Polar Regions, i.e. source areas of $\mathrm{BC}$ and transport. The change of DRF at surface is relatively small globally $\left(0.09 \mathrm{~W} \mathrm{~m}^{-2}\right)$ but it could be significant locally, e.g. over Asia.

\section{Summary}

The objective of this study is to investigate aerosol DRF and discuss its uncertainties based on a size-resolved advanced particle microphysics (GEOS-Chem-APM) model. The APM model is designed to capture the main particle properties (sizes, compositions, coating of primary particles by secondary species, etc.) important for their radiative forcing while keeping the computational costs affordable. APM treats particles of different types (SS, BC, dust, sea salt, POC) as semi-externally mixed. The aerosol information resolved by the APM model is employed to simulate and investigate global aerosol DRF, particularly due to anthropogenic aerosols. The GEOS-Chem-APM model has been extended by incorporating a radiation transfer model. The resulting model has been used to investigate the aerosol DRF and the uncertainties of the results on assumption of mixing state, size and density of particles.
The simulated aerosol burden for each species is generally in good agreement with AeroCom model results in terms of both global annual mean and spatial distribution. The surface concentrations (sulfate and BC) are slightly lower than the observations, especially over Asia and remote regions, indicating that the emission inventories in these regions need to be updated to better agree with observations. Parameterizations of physical processes, including dry and wet deposition, transport and vertical mixing, could also contribute to the discrepancies. Further studies are needed in the future to improve the model simulations.

To obtain the optical properties, the online simulated aerosol size distribution in the model is applied as input to Mie calculations and the effect of coating on BC and dust particles is considered. The required refractive indices for various aerosol species are taken from the values reported in recent publications. As aerosol radiative forcing is strongly dependent on surface condition (i.e. surface albedo), a dataset with high temporal and spatial resolution (8 day mean at $5.6 \mathrm{~km}$ resolution), and spectral-dependent from MODIS was applied in the study.

We compared the GEOS-Chem-APM simulated AOD with MISR and MODIS satellite data, and AERONET observations. Overall, the model could capture the basic spatial pattern of AOD, and the magnitudes over the major source regions are comparable to observations. The DRF at TOA and 
surface from total aerosols (anthropogenic and natural) are calculated as -5.69 and $-6.84 \mathrm{~W} \mathrm{~m}^{-2}$ for clear sky, and reduced to -4.14 and $-5.33 \mathrm{~W} \mathrm{~m}^{-2}$ for all sky as clouds block part of solar radiation. The LW radiative forcing is considered in this study for mineral dust only. The magnitude could be high in the regional scale (up to $1 \mathrm{~W} \mathrm{~m}^{-2}$ at TOA for all sky), but negligible in global mean $\left(0.1 \mathrm{~W} \mathrm{~m}^{-2}\right)$ compared with SW radiative forcing $\left(-4.1 \mathrm{~W} \mathrm{~m}^{-2}\right)$.

Compared to the total aerosols, anthropogenic aerosols are believed to exhibit a progressively more important impact on climate change since the Industrial Revolution. According to the IPCC AR4 report, the estimation of global mean DRF by anthropogenic aerosols range from -0.1 to $-0.9 \mathrm{~W} \mathrm{~m}^{-2}$, with the best estimate of $-0.5 \mathrm{~W} \mathrm{~m}^{-2}$. Our simulations gave the DRF at TOA for all sky as $-0.41 \mathrm{~W} \mathrm{~m}^{-2}$, which is within the range given by IPCC AR4 report (2007). The corresponding atmospheric and surface DRF is 0.71 and $-1.13 \mathrm{~W} \mathrm{~m}^{-2}$, respectively.

The sensitivity studies indicate that reducing the size of $\mathrm{BC}$ and $\mathrm{POC}$ particles by $50 \%$ can significantly impact the simulated DRF, with the DRF at TOA increasing to $-0.08 \mathrm{~W} \mathrm{~m}^{-2}$, but will not cause any significant impact on surface DRF. On the contrary, by applying a smaller BC density $\left(1.2 \mathrm{~g} \mathrm{~cm}^{-3}\right)$ in the model rather than $1.8 \mathrm{~g} \mathrm{~cm}^{-3}$ as in the base run, will not cause major changes to the DRF at TOA, but significantly enhance the atmospheric absorption and thus induce stronger cooling at surface. The effect of the mixing state on DRF is examined by replacing coating in the base run with no coating. The results show that DRF at TOA will become more negative due to weaker atmospheric absorption (decrease $0.29 \mathrm{~W} \mathrm{~m}^{-2}$ ), and will not cause a significant change to DRF at surface.

Acknowledgements. We would like to thank Jiangnan Li from Canadian Centre for Climate Modeling and Analysis (CCCma) for providing 1-D radiation transfer model, and Dorothy Koch for providing observed BC surface concentration. The data for AOD from MODIS and MISR were downloaded using the GES-DISC Interactive Online Visualization and Analysis Infrastructure, a part of the NASA's Goddard Earth Sciences Data and Information Services Center and AERONET data were obtained from NASA Goddard Space Flight Center. The MODIS L1B data were obtained through the online Data Pool at the NASA Land Processes Distributed Active Archive Center (LP DAAC), USGS/Earth Resources Observation and Science (EROS) Center, Sioux Falls, South Dakota (http://lpdaac.usgs.gov/get_data). This study is supported by NASA under grant NNX11AQ72G, NSF under grant AGS-0942106 and DOE under grant DE-SC0002199. The GEOS-Chem model is managed by the Atmospheric Chemistry Modeling Group at Harvard University with support from NASA's Atmospheric Chemistry Modeling and Analysis Program.

Edited by: J. Quaas

\section{References}

Ackerman, T. P. and Toon, O. B.: Absorption of visible radiation in atmosphere containing mixtures of absorbing and non-absorbing particles, Appl. Opt., 20, 3661-3668, 1981.

Aouizerats, B., Thouron, O., Tulet, P., Mallet, M., Gomes, L., and Henzing, J. S.: Development of an online radiative module for the computation of aerosol optical properties in 3-D atmospheric models: validation during the EUCAARI campaign, Geosci. Model Dev., 3, 553-564, doi:10.5194/gmd-3-553-2010, 2010.

Balkanski, Y., Schulz, M., Claquin, T., and Guibert, S.: Reevaluation of Mineral aerosol radiative forcings suggests a better agreement with satellite and AERONET data, Atmos. Chem. Phys., 7, 81-95, doi:10.5194/acp-7-81-2007, 2007.

Bey, I., Jacob, D., Yantosca, R., Logan, J., Field, B., Fiore, A., Li, Q., Liu, H., Mickley, L., and Schulz, M.: Global modeling of tropospheric chemistry with assimilated meteorology: Model description and evaluation, J. Geophys. Res., 106, 23073-23096, 2001.

Bond, T. C. and Bergstrom, R. W.: Light absorption by carbonaceous particles: An investigative review, Aerosol Sci. Technol., 40, 27-67, doi:10.1080/02786820500421521, 2006.

Bond, T. C., Streets, D. G., Yarber, K. F., Nelson, S. M., Woo, J.-H., and Klimont, Z.: A technology-based global inventory of black and organic carbon emissions from combustion. J. Geophys. Res., 109, D14203, dot:10.1029/2003JD003697, 2004.

Bond, T. C., Ehardwaj, E., Dong, R., Jogani, R., Jung, S., Roden, C., Strrets, D. G., and Trautmann, N. M.: Historical emissions of black and organic carbon aerosol from energy related combustion, 1850-2000, Global Biogeochem. Cy., 21, GB2018, doi:10.1029/2006GB002840, 2007.

Chin, M., Jacob, D. J., and Gardner, G. M.: A global threedimensional model of tropospheric sulfate, J. Geophys. Res., 101, 18667-18690, 1996.

Chylek, P., Videen, G., Ngo, D., Pinnick, R., Ronald, G., and Klett, J. D.: Effect of black carbon on the optical properties and climate forcing of sulfate aerosols, J. Geophys. Res., 100, 16325-16332, 1995.

Cooke, W. F., Liousse, C., Cachier, H., and Feichter, J.: Construction of a $1^{\circ} \times 1^{\circ}$ fossil fuel emission data set for carbonaceous aerosol and implementation and radiative impact in the ECHAM4 model, J. Geophys. Res., 104, 22137-22162, 1999.

Côté, J., Desmarais, J.-G., Gravel, S., Methot, A., Roch, M., and Staniforth, A.: The operational CMC/MRB Global Envionrmental Multiscale (GEM) model. Part 1: Design considerations and formulation, Mon. Weather Rev., 126, 1373-1395, 1998.

Dentener, F., Kinne, S., Bond, T., Boucher, O., Cofala, J., Generoso, S., Ginoux, P., Gong, S., Hoelzemann, J. J., Ito, A., Marelli, L., Penner, J. E., Putaud, J.-P., Textor, C., Schulz, M., van der Werf, G. R., and Wilson, J.: Emissions of primary aerosol and precursor gases in the years 2000 and 1750 prescribed data-sets for AeroCom, Atmos. Chem. Phys., 6, 4321-4344, doi:10.5194/acp-64321-2006, 2006.

Dobbie, J., Li, J., and Chýlek, P.: Two and four stream optical properties for water clouds and solar wavelengths, J. Geophys. Res., 104, 2067-2079, 1999.

Eastwood, P.: Particulate emissions from vehicles, SBN 0470724552, John Wisley and Sons, Chichester, UK, 2008. 
Evans, M. J. and Jacob, D. J.: Impact of new laboratory studies of N2O5 hydrolysis on global model budgets of tropospheric nitrogen oxides, ozone, and OH, Geophys. Res. Lett., 32, L09813, doi:10.1029/2005GL022469, 2005.

Fairlie, D. T., Jacob, D. J., and Park, R. J.: The impact of transpacific transport of mineral dust in the United States, Atmos. Environ., 41, 1251-1266, 2007.

Fountoukis, C. and Nenes, A.: ISORROPIA II: a computationally efficient thermodynamic equilibrium model for $\mathrm{K}^{+}$. $\mathrm{Ca}^{2+}-\mathrm{Mg}^{2+}-\mathrm{NH}_{4}^{+}-\mathrm{Na}^{+}-\mathrm{SO}_{4}^{2-}-\mathrm{NO}_{3}^{-}-\mathrm{Cl}^{-}-\mathrm{H}_{2} \mathrm{O}$ aerosols, Atmos. Chem. Phys., 7, 4639-4659, doi:10.5194/acp-7-4639-2007, 2007.

$\mathrm{Fu}, \mathrm{Q}$.: An accurate parameterization of the solar radiative properties of cirrus clouds for climate models, J. Climate, 9, 20582082, 1996.

Fu, Q., Yang, P., and Sun, W.: An accurate parameterization of the infrared radiative properties of cirrus clouds for climate models, J. Climate, 11, 2223-2237, 1998.

Gong, S. L., Barrie, L. A., Prospero, J. M., Savoie, D. L., Ayersand, G. P., Blanchet, J.-P., and Spacek, L.: Modeling sea salt aerosols in the atmosphere 2. Atmospheric concentrations and fluxes, J. Geophys. Res., 102, 3819-3830, 1997.

Guenther, A., Karl, T., Harley, P., Wiedinmyer, C., Palmer, P. I., and Geron, C.: Estimates of global terrestrial isoprene emissions using MEGAN (Model of Emissions of Gases and Aerosols from Nature), Atmos. Chem. Phys., 6, 3181-3210, doi:10.5194/acp-63181-2006, 2006.

Holben, B: AERONET: A federated instrument network and data archived for aerosol characterization, Remote. Sens. Envion., 66, 1-16, 1998.

Intergovermental Panel on Climate Change (IPCC), First Assessment Report, Cambridge Univ. Press, New York, 1990.

Intergovermental Panel on Climate Change (IPCC), Third Assessment Report, Cambridge Univ. Press, New York, 2001.

Intergovermental Panel on Climate Change (IPCC), Fourth Assessment Report, Cambridge Univ. Press, New York, 2007.

Jacobson, M. Z.: A physically-based treatment of elemental carbon optics: Implications for global direct forcing of aerosols, Geophys. Res. Lett., 27, 217-220, 2000.

Jacobson, M. Z.: Strong radiative heating due to the mixing state of black carbon in atmospheric aerosols, Nature, 409, 695-697, 2001.

Jaeglé, L., Quinn, P. K., Bates, T. S., Alexander, B., and Lin, J.-T.: Global distribution of sea salt aerosols: new constraints from in situ and remote sensing observations, Atmos. Chem. Phys., 11, 3137-3157, doi:10.5194/acp-11-3137-2011, 2011.

Kaufman, Y. J., Tanré, D., Remer, L. A., Vermote, E. F., Chu, A., and Holben, B. N.: Operational remote sensing of tropospheric aerosol over the land from EOS-MODIS, J. Geophys. Res., 102, 17051-17061, 1997.

Kinne, S., Schulz, M., Textor, C., Guibert, S., Balkanski, Y., Bauer, S. E., Berntsen, T., Berglen, T. F., Boucher, O., Chin, M., Collins, W., Dentener, F., Diehl, T., Easter, R., Feichter, J., Fillmore, D., Ghan, S., Ginoux, P., Gong, S., Grini, A., Hendricks, J., Herzog, M., Horowitz, L., Isaksen, I., Iversen, T., Kirkevåg, A., Kloster, S., Koch, D., Kristjansson, J. E., Krol, M., Lauer, A., Lamarque, J. F., Lesins, G., Liu, X., Lohmann, U., Montanaro, V., Myhre, G., Penner, J., Pitari, G., Reddy, S., Seland, O., Stier, P., Takemura, T., and Tie, X.: An AeroCom initial assessment - optical properties in aerosol component modules of global models, Atmos. Chem. Phys., 6, 1815-1834, doi:10.5194/acp-6-1815-2006, 2006.

Koch, D., Bond, T., Streets, D., Unger, N., and van der Werf, G. R.: Global impacts of aerosols from particular source regions and sectors, J. Geophys. Res., 112, D02205, doi:10.1029/2005JD007024, 2007.

Koch, D., Schulz, M., Kinne, S., McNaughton, C., Spackman, J. R., Balkanski, Y., Bauer, S., Berntsen, T., Bond, T. C., Boucher, O., Chin, M., Clarke, A., De Luca, N., Dentener, F., Diehl, T., Dubovik, O., Easter, R., Fahey, D. W., Feichter, J., Fillmore, D., Freitag, S., Ghan, S., Ginoux, P., Gong, S., Horowitz, L., Iversen, T., Kirkevåg, A., Klimont, Z., Kondo, Y., Krol, M., Liu, X., Miller, R., Montanaro, V., Moteki, N., Myhre, G., Penner, J. E., Perlwitz, J., Pitari, G., Reddy, S., Sahu, L., Sakamoto, H., Schuster, G., Schwarz, J. P., Seland, Ø., Stier, P., Takegawa, N., Takemura, T., Textor, C., van Aardenne, J. A., and Zhao, Y.: Evaluation of black carbon estimations in global aerosol models, Atmos. Chem. Phys., 9, 9001-9026, doi:10.5194/acp-9-9001-2009, 2009.

Krekov, M.: Aerosols Effects on Climate, Univerity of Arizona Press, USA, 9-72, 1993.

Lesins, G., Chylek, P., and Lohmann, U.: A study of internal and external mixing scenarios and its effect on aerosol optical properties and direct radiative forcing, J. Geophys. Res., 107, 4094, doi:10.1029/2001JD000973, 2002.

Linder, T. H. and Li, J.: Parameterization of the optical properties for water clouds in the infrared, J. Climate, 13, 1797-1805, 2000.

Li, J.: Accounting for Unresolved Clouds in a 1D Infrared Radiative Transfer Model. Part I: Solution for Radiative Transfer, Including Cloud Scattering and Overlap, J. Atmos. Sci., 59, 3302-3320, 2002.

Li, J. and Barker, H. W.: Accounting for unresolved clouds in a 1D infrared radiative transfer model. Part II: Horizontal variability of cloud water path, J. Atmos. Sci., 59, 3321-3339, 2002.

Li, J. and Barker, H.: A radiation algorithm with correlated-k distribution. Part I: Local thermal equilibrium, J. Atmos. Sci., 62, 286-309, 2005.

Li, J., Ma, X., von Salzen, K., and Dobbie, S.: Parameterization of sea-salt optical properties and physics of the associated radiative forcing, Atmos. Chem. Phys., 8, 4787-4798, doi:10.5194/acp-84787-2008, 2008.

Liao, H. and Seinfeld, J. H.: Radiative forcing by mineral dust aerosols: sensitivity to key variables, J. Geophys. Res., 103, 31637-31645, 1998.

Liao, H., Henze, D. K., Seinfeld, J. H., Wu, S., and Mickey, L. J.: Biogenic secondary organic aerosol over the United States: Comparison of climatological simulations with observations, J. Geophys. Res., 112, D06201, doi:10.1029/2006JD007813, 2007.

Liu, X., Penner, J. E., and Herzog, M.: Global modeling of aerosol dynamics: Model description, evaluation and interaction between sulfate and nonsulfate aerosols, J. Geophys. Res., 110, D18206, doi:10.1029/2004JD005674, 2005.

Liu, X., Penner, J. E., Das, B., Bergmann, D., Rodriguez, J. M., Strahan, S., Wang, M., and Feng, Y.: Uncertainties in global aerosol simulations: Assessment using three meteorological data sets, J. Geophys. Res., 112, D11212, doi:10.1029/2006JD008216, 2007.

Lohmann, U., von Salzen, K., McFarlane, N., Leighton, H. G., and Feichter, J.: Tropospheric sulphur cysle in the Canadian General 
Circulation model, J. Geophys. Res., 104, 26833-26858, 1999.

Ma, X. and von Salzen, K.: Dynamics of the sulphate aerosol size distribution on a global scale, J. Geophys. Res., 111, D08206, doi:10.1029/2005JD006620, 2006.

Ma, X., von Salzen, K., and Li, J.: Modelling sea salt aerosol and its direct and indirect effects on climate, Atmos. Chem. Phys., 8, 1311-1327, doi:10.5194/acp-8-1311-2008, 2008.

Ma, X., von Salzen, K., and Cole, J.: Constraints on interactions between aerosols and clouds on a global scale from a combination of MODIS-CERES satellite data and climate simulations, Atmos. Chem. Phys., 10, 9851-9861, doi:10.5194/acp-10-98512010, 2010.

Mark, G., Kuhns, H., Pitchford, M., Dietz, R., Ashbaugh, L., and Watson, T.: Application of the Tracer-Aerosol Gradient Interpretive Technique (TAGIT) to sulfur attribution for the Big Bend Regional Aerosol and Visibility Observational (BRAVO) Study, JAPCA J. Air Waste Ma., 53, 586-595, 2003.

Martin, R. V., Jacob, D. J., Yantosca, R. M., Chin, M., and Ginoux, P.: Global and regional decreases in tropospheric oxidations from photochemical effects of aerosols, J. Geophys. Res., 108, 4097, doi:10.1029/2002JD002622, 2003.

Martonchik, J. V., Diner, D. J., Kahn, R. A., Ackerman, T. P., Verstraete, M. M., Pinty, B., and Gordon, H. R.: Techniques for the retrieval of aerosol properties over land and ocean using multiangle imaging, IEEE T. Geosci. Remote Sens., 36, 1212-1227, 1998.

McFarlane, N., Boer, G., Blanchet, J.-P., and Lazare, M.: The Canadian Climate Centre Second-Generation Circulation Model and its equilibrium climate, J. Climate, 5, 1013-1044, 1992.

Murphy, D. M., Anderson, J. R., Quinn, P. K., McInnes, L. M., Brechtel, F. J., Kreidenweis, S. M., Middlebrook, A. M., Pósfai, M., Thomson, D. S., and Buseck, P. R.: Influence of sea-salt on aerosol radiative properties in the Southern Ocean marine boundary layer, Nature, 392, 62-65, doi:10.1038/32138, 1998.

NASA Land Processes Distributed Active Archive Center (LP DAAC). ASTER L1B. USGS/Earth Resources Observation and Science (EROS) Center, Sioux Falls, South Dakota, 2001.

Olivier, J. G. J., Berdowski, J. J. M., Peters, J. A. H. W., Bakker, J., Visschedijk, A. J. H., and Bloos, J.-P. J.: Applications of EDGAR. Including a description of EDGER 3.0: reference database with trend data for 1970-1995, RIVM, Bilthoven, RIVM report no. 773301 001/NOP report no. 4102200051 , 2001.

Park, R. J.: Natural and transboundary pollution influences on sulfate-nitrate-ammonium aerosols in the United States: Implications for policy, J. Geophys. Res., 109, D15204, doi:10.1029/2002JD003190, 2004.

Park, R. J., Jacob, D. J., Kumar, N., and Yantosca, R. M.: Regional visibility statistics in the United States: Natural and transboundary pollution influences, and implications for the Regional Haze Rule, Atmos. Environ., 40, 5405-5423, 2006.

Remer, L. A., Kaufman, Y. J., Tanré, D., Mattoo, S., Chu, D. A., Martins, J. V., Li, R.-R., Ichoku, C., Levy, R. C., Kleidman, R. G., Eck, T. F., Vermote, E., and Holben, B. N.: The MODIS algorithm, products and validation, J. Atmos. Sci., 62, 947-973, 2005.

Schnaiter, M., Linke, C., Mohler, O., Naumann, K.-M., Saathoff, H., and Wagner, R.: Absorption amplification of black carbon internally mixed with secondary organic aerosol, J. Geophys. Res.,
110, D19204, doi:10.1029/2005JD006046, 2005.

Scinocca, J. F., McFarlane, N. A., Lazare, M., Li, J., and Plummer, D.: Technical Note: The CCCma third generation AGCM and its extension into the middle atmosphere, Atmos. Chem. Phys., 8, 7055-7074, doi:10.5194/acp-8-7055-2008, 2008.

Schulz, M., Textor, C., Kinne, S., Balkanski, Y., Bauer, S., Berntsen, T., Berglen, T., Boucher, O., Dentener, F., Guibert, S., Isaksen, I. S. A., Iversen, T., Koch, D., Kirkevåg, A., Liu, X., Montanaro, V., Myhre, G., Penner, J. E., Pitari, G., Reddy, S., Seland, $\varnothing$., Stier, P., and Takemura, T.: Radiative forcing by aerosols as derived from the AeroCom present-day and pre-industrial simulations, Atmos. Chem. Phys., 6, 5225-5246, doi:10.5194/acp-65225-2006, 2006.

Stier, P., Seinfeld, J. H., Kinne, S., and Boucher, O.: Aerosol absorption and radiative forcing, Atmos. Chem. Phys., 7, 5237-5261, doi:10.5194/acp-7-5237-2007, 2007.

Streets, D. G., Bond, T. C., Carmichael, G. R., Fernandes, S. D., Fu, Q., He, D., Klimont, Z. Nelson, S. M., Tsai, N. Y., Wang, M. Q., Woo, J.-H., and Yarber, K. F.: An inventory of gaseous and primary aerosol emissions in Asia in the year 2000, J. Geophys. Res., 108, 8809, doi:10.1029/2002JD003093, 2003.

Takemura, T., Okamoto, H., Maruyama, Y., Numagati, A., Higurashi, A., and Nakajima, T.: Global three-dimensional simulation of aerosol optical thickness distribution of various origins, J. Geophys. Res., 105, 17853-17873, 2000.

Talbot, D., Moran, M. D., Bouchet, V., Crevier, L.-P., Menard, S., and Kallaur, A.: Development of a new Canadian operational air quality forecast model. Air Pollution Modeling and Its Application XLX, Springer Science + Busuness Media BV, 2008.

Textor, C., Schulz, M., Guibert, S., Kinne, S., Balkanski, Y., Bauer, S., Berntsen, T., Berglen, T., Boucher, O., Chin, M., Dentener, F., Diehl, T., Feichter, J., Fillmore, D., Ginoux, P., Gong, S., Grini, A., Hendricks, J., Horowitz, L., Huang, P., Isaksen, I. S. A., Iversen, T., Kloster, S., Koch, D., Kirkevåg, A., Kristjansson, J. E., Krol, M., Lauer, A., Lamarque, J. F., Liu, X., Montanaro, V., Myhre, G., Penner, J. E., Pitari, G., Reddy, M. S., Seland, Ø., Stier, P., Takemura, T., and Tie, X.: The effect of harmonized emissions on aerosol properties in global models an AeroCom experiment, Atmos. Chem. Phys., 7, 4489-4501, doi:10.5194/acp-7-4489-2007, 2007.

van der Werf, G. R., Randerson, J. T., Giglio, L., Collatz, G. J., Kasibhatla, P. S., and Arellano Jr., A. F.: Interannual variability in global biomass burning emissions from 1997 to 2004, Atmos. Chem. Phys., 6, 3423-3441, doi:10.5194/acp-6-3423-2006, 2006.

Weimer, S., Mohr, C., Richter, R., Keller, J., Mohr, M., Prévôt, A. S. H., and Baltensperger, U.: Mobile measurements of aerosol number and volume size distributions in an Alpine valley: Influence of traffic versus wood burning, Atmos. Environ., 43, 624-630, 2009.

Yu, F.: Ion-mediated nucleation in the atmosphere: Key controlling parameters, implications, and look-up table, J. Geophys. Res., 115, D03206, doi:10.1029/2009JD012630, 2010.

Yu, F.: A secondary organic aerosol formation model considering successive oxidation aging and kinetic condensation of organic compounds: global scale implications, Atmos. Chem. Phys., 11, 1083-1099, doi:10.5194/acp-11-1083-2011, 2011.

Yu, F. and Luo, G.: Simulation of particle size distribution with a global aerosol model: contribution of nucleation to aerosol 
and CCN number concentrations, Atmos. Chem. Phys., 9, 76917710, doi:10.5194/acp-9-7691-2009, 2009.

Yu, F., Luo, G., Bates, T., Anderson, B., Clarke, A., Kapusin, V., Yantosca, R., Wang, Y., and Wu, S.: Spatial distributions of particle number concentrations in the global troposphere: Simulations, observations, and implications for nucleation mechanisms, J. Geophys. Res., 115, D17205, doi:10.1029/2009JD013473, 2010.

Yu, F., Luo, G., and Ma, X.: Regional and global modelling of aerosol optical properties with a size, composition, and mixing state resolved particle microphysics model, Atmos. Chem. Phys. Discuss., 12, 93-128, doi:10.5194/acpd-12-93-2012, 2012.
Yu, H., Kaufman, Y. J., Chin, M., Feingold, G., Remer, L. A., Anderson, T. L., Balkanski, Y., Bellouin, N., Boucher, O., Christopher, S., DeCola, P., Kahn, R., Koch, D., Loeb, N., Reddy, M. S., Schulz, M., Takemura, T., and Zhou, M.: A review of measurement-based assessments of the aerosol direct radiative effect and forcing, Atmos. Chem. Phys., 6, 613-666, doi:10.5194/acp-6-613-2006, 2006.

Zhang, X., Wang, Y., Zhang, X., Guo, W., and Gong, S. L.: Carbonaceous aerosol composition over various regions of China during 2006, J. Geophys. Res., 113, D14111, doi:10.1029/2007JD009525, 2009. 